\title{
THE CONCEPT OF ELECTRON
}

ACTIVITY AND ITS RELATION TO REDOX POTENTIALS IN AQUEOUS GEOCHEMICAL SYSTEMS by Donald C. Thorstenson

U.S. GEOLOGICAL SURVEY Open-File Report 84-072 1984 Bnchule a $Z$-page enata

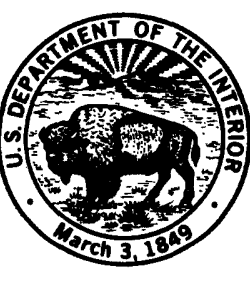




\section{UNITED STATES DEPARTMENT OF THE INTERIOR}

WILLIAM T. CLARK, Secretary

\section{GEOLOGICAL SURVEY}

Dallas L. Peck, Director

For additional information write to:

Regional Research Hydrologist

U.S. Geological Survey Water Resources Division 432 National Center Reston, Virginia 22092
Copies of this report may be purchased from:

U.S. Geological Survey Western Distribution Branch Open-File Services Section Box 25425, Federal Center Denver, Colorado 80225 
ERRATA: (p. 1)

1. Equation (2), p. 3 , should read:

$$
E_{1}=E_{C}^{0}+\frac{2.30 R T}{F} \log \frac{1}{C_{H^{+}}}=E_{C}^{0}+\frac{2.30 R T}{F} p H .
$$

2. Table 1 , p. 6 , entry 5 , should read:

$$
\text { In pure water, } p \varepsilon \sim 6.9 \text {; }
$$

3. Line 3, paragraph 3, p. 10 should read:

$$
\text { As } \mathrm{Fe}^{3+}(\mathrm{aq}) \text { is converted to } \mathrm{Fe}^{2+}(\mathrm{aq}) \text { via equation (15) to }
$$

4. Equation (22), p. 13, should read:

$$
K=\frac{a^{n} e^{-}(a q){ }^{a} 0 x_{(a q)}^{n+}}{a_{\text {REn }}(a q)} .
$$

5. Equation (38), p. 18 , should read:

$$
-\log a_{e^{-}}(a q)=\frac{F}{2.303 R T} E h+\frac{\mu^{\circ} e^{-}(a q)}{2.303 R T} \text {. }
$$

6. Equation (52), p.23, should read:

$$
\mathrm{a}_{\mathrm{e}^{-}}(\mathrm{aq})=10^{-55.5} ; \quad \mathrm{pe}^{-}{ }_{(\mathrm{aq})}=55.5 \text {, }
$$

7. Equation (53), p. 23 , should read:

$$
p \varepsilon \cong+6.9 \text { and } E h \cong+0.41 \text { volt. }
$$

8. Equation $(54 c)$, p. 23 , should read:

$$
m_{e^{-}}(a q)-10^{-55.5} \text {. }
$$


ERRATA: (p. 2)

9. The second line from the bottom, p. 28 , should read:

(a state that has been maintained for $\simeq 10^{5}$ years based on $\ldots$.

10. The heading of Table 2, p. 29, should read:

\begin{tabular}{l}
\hline $\begin{array}{l}\text { Constituent } \\
\text { or } \\
\text { Property }\end{array}$ \\
\hline
\end{tabular}

11. The note at the bottom of Table 2, p. 29, should read:

Concentrations of dissolved species are in mmol/liter. Data from Thorstenson and others, 1979.

12. The chemical reaction at the top of $p .35$, when balanced, should read:

$$
\mathrm{Fe}^{2+}+2 \mathrm{H}_{2} \mathrm{O}(1)=\mathrm{FeOOH}(\mathrm{s})+3 \mathrm{H}^{+}(\mathrm{aq})+\mathrm{e}^{-}(\mathrm{aq}) \text {, }
$$




\section{CONTENTS}

Abstract

Introduction

Historical perspective

Electrochemical Principles

Potential differences across two (or more) interfaces -

Definition of $\mathrm{pH}$

Definition of $p \varepsilon-5$

Comparison of $\mathrm{pH}$ and $\mathrm{pe}$ definitions 6

Potential differences across one (or less) interfaces - 8

The electrochemical potential

Redox potentials and electrostatic potentials

The concept of electron activity in aqueous solutions _-

The hydrated electron - 14

Electrochemical conventions: Eh, p $\varepsilon$, and electron activi ty 15

Redox potentials in aqueous geochemistry

Equilibrium systems

Di sequilibrium systems - 25

Total di sequili brium - 25

Partial di sequilibrium - 26

Example - 28

Practical considerations 31

Interpretation and modeling of redox processes
Chemical modeling

Rema rks - 37

Conc lusions

Ackn owledgments-

References- 


\section{ILLUSTRATIONS}

Page

Figure 1. Schematic representation of an Eh measurement-_ 12

Figure 2. The water stability field represented as a function of $\mathrm{pH}$, $\mathrm{pe}^{-}(\mathrm{aq}), \mathrm{p} \varepsilon$, and $\mathrm{Eh}-20$

Figure 3. The chemical basis for Berner's sedimentary environment classification

TABLES

Table 1. The pe - pH analogy (?)

Table 2. Chemi stry of water from the Fox Hills aquffer 
THE CONCEPT OF ELECTRON ACTIVITY AND ITS RELATION

TO REDOX POTENTIALS IN AQUEOUS GEOCHEMICAL SYSTEMS

By

Donald C. Thorstenson

\section{ABSTRACT}

The definition of a formal thermodynamic activity of electrons in redox reactions appears in the literature of the $1920^{\prime} \mathrm{s}$. The concept of $p \varepsilon$ as $-\log _{10}$ [electron activity] was introduced by Jorgensen in 1945 and popularized in the geochemical literature by Sillen, who considered $p \varepsilon$ and $\mathrm{pH}$ as master variables in geochemical reactions. The physical significance of the concept of electron activity was challenged as early as 1928. However, only in the last two decades have sufficient thermodynamic data become available to examine this question quantitatively.

The chemical nature of hydrated electrons differs greatly from that of hydrated protons, and thermodynamic data show that hydrated electrons cannot exist at physically meaningful equilibrium concentrations under natural conditions. This has important consequences for the understanding of redox processes in natural waters. These are: (1) the analogy between $p \varepsilon$ and $\mathrm{pH}$ as master variables is generally carried much further than is justified; (2) a thermodynamically meaningful value of redox potential cannot be assigned to disequilibrium systems; (3) the most useful approach to the study of redox characteristics Is the analysis and study of multiple redox couples in the system; and (4) for all practical purposes, thermodynamically defined redox potentials do not exist (and thus cannot be measured) in natural waters.

The overall implication for natural systems is that, in terms of redox reactions, each case must be considered on an individual and detalled basis. Field studies would appear to be a mandatory part of any site-specific study; conclusions regarding redox processes cannot be based solely on electrode measurements or thermodynamic stability calculations.

\section{INTRODUCTION}

The use of $\mathrm{p} \varepsilon$ (as opposed to $\mathrm{Eh}$ ) and $\mathrm{pH}$ as "master variables" to describe aqueous redox reactions is a concept introduced to the geochemical literature in the late 1960's (Morris and Stumm, 1967; Sillen, 1967; Truesde11, 1968). Since that time, the use of the $p \varepsilon$ parameter, credited to Jorgensen (1945) as - $\log 10$ [electron activity], 1/ has found increasing use (cf. Thorstenson, 1970;

\footnotetext{
1/ Jorgensen actually defined $p \varepsilon$ in terms of electron concentration.
} 
Stumm and Morgan, 1970; 1981). However, a rigorous treatment of the thermodynamic assumptions inherent in the concept of electron activity and the definition of the $p \varepsilon$ parameter has not, to the author's knowledge, appeared since the work of W. M. Clark $(1922,1928)$. The theoretical treatment of the conceptual and mechanistic problems dealt with in the early literature appears to have been partially lost with the passage of time, with the result that the analogy between $\mathrm{p} \varepsilon$ and $\mathrm{pH}$ is stressed too heavily, particularly as applied to studies of natural systems that are not at redox equilibrium.

This paper is an outgrowth of work carried out with John D. Hostettler, University of Colorado, Colorado Springs. Hostettler (1983) summarizes the pertinent characteristics of solvated electrons and presents a mathematical treatment of redox reactions in geochemical systems. The emphasis of the present paper is primarily on the introduction and use of the electron activity concept in geochemistry and its relation to the parameters $p \varepsilon$ and Eh.

The specific goals of this paper are 1) to reintroduce some of the concepts considered by Clark; 2) to demonstrate with a simple example the use of electrochemical potential in dealing with redox reactions; 3) to show how modern thermodynamic data on the hydrated electron relate to the formal concept of $p \varepsilon$; and 4) to examine the implications of these topics for the study and interpretation of redox processes in natural waters.

\section{HISTORICAL PERSPECTIVE}

The concept of $\mathrm{pH}$ as $-\log \left[\mathrm{H}^{+}\right.$(aq) concentration], or $-\log \mathrm{c}_{\mathrm{H}}^{+}$, was introduced by Sфrensen (1909), and later modified to $\mathrm{pH}=-\log \left[\mathrm{H}^{+}\right.$(aq) activity],

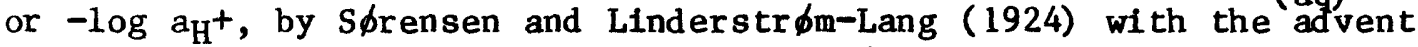

of the concept of thermodynamic activity (Lewis, 1913; Lewis and Randal1, 1923). The concept of electron activity in redox reactions was introduced by Clark (1922) and received an extensive discussion by Clark (1928) . An additional commentary on conventions applied to electrons in metals was provided by Michaelis (1930). In his 1928 book Clark considered separately the chemical and electrical effects of electrons in redox reactions, a concept that was later generalized and formalized as the electrochemical potential (Brфnsted, 1929; Guggenheim, $1929,1930)$. The use of the electrochemical potential concept in the theoretical treatment of redox reactions seems to have escaped the formal geochemical 1iterature; thorough discussions can be found in the physical chemistry literature (Guggenheim, 1949; Harned and Owen, 1958; Bockris and Reddy, 1970; Castellan, 1970).

In 1945, Jфrgensen coined the term $p \varepsilon\left(\equiv \log 1 / c_{\text {electron }}\right)$ in a manner analogous to the early definitions of $\mathrm{pH}$. However, Jorgensen in fact did nothing more than formalize concepts already presented by Clark (1928), and provided the name $p \varepsilon$. Many of the mechanistic and theoretical problems that concerned Clark appear to have been overlooked by Jørgensen. The formal definition of $p \varepsilon$ was introduced to the United States chemical literature by Sillen (1952) and to the geochemical literature in references already cited. 
In the last two decades, sufficient data have accumulated to allow estimation of the Gibbs free energy of the hydrated electron (see Hart and Anbar, 1970; Hostettler, 1983). These data provide the information necessary to discuss electron activity on an absolute, rather than relative, basis (see Truesde11, 1968). The implications of the hydrated electron data have not received sufficient emphasis. With the exponentially increasing application of geochemical studies to practical problems such as toxic waste disposal, the concepts involved need $f$ urther exami nation and study.

\section{ELECTROCHEMICAL PRINCIPLES}

\section{Potential Differences Across.Two (or more) Interfaces}

A fundamental principle of electrochemistry is that the potential difference across a single interface cannot be measured (see Bockris and Reddy, 1970 , p. 659, for a concise summary of measurable and unmeasurable potential differences). Thus, this discussion begins with measurable quantities involving more than one electrode or interface.

$$
\text { Definition of } \mathrm{pH}^{1 /}
$$

S $\phi$ rensen (1909) originally defined the $\mathrm{pH}$ scale based on a series of measurements with electrochemical cells consisting of a hydrogen electrode (of varying hydrogen ion concentrations) with a $\mathrm{KCl}$ salt bridge and a calome 1 reference electrode. Based on the concepts of Nernst (1897) and Peters (1898), as they existed at that time, the difference in electromotive force between two cells at different hydrogen ion concentrations was expressed as

$$
E_{1}-E_{2}=\frac{R T}{F} \ln \frac{c_{H_{2}^{+}}}{c_{H_{1}^{+}}}
$$

If $c_{\mathrm{H}^{+}}$is fixed at unity, $\mathrm{E}_{2}$ will have a definite value at any given temperature and equation (1) can be written

$$
\mathrm{E}_{1}=\mathrm{E}_{\mathrm{c}}^{\mathrm{O}}+\frac{2.30 \mathrm{RT}}{\mathrm{F}} \log \frac{1}{\mathrm{c}_{\mathrm{H}^{+}}}=\mathrm{E}_{\mathrm{c}}^{\mathrm{O}}-\frac{2.30 \mathrm{RT}}{\mathrm{F}} \mathrm{pH}
$$

1/ The following is excerpted from the discussion presented by Bates (1973), chap. 2 .

2/ The conventions $\Delta G=+n E F$ and $\Delta G=-n E F$ are both used by various authors cited in this text. The original authors' notation is preserved unless specifically noted. 
or, with appropriate numerical values for the constants at $25^{\circ} \mathrm{C}$,

$$
\mathrm{pH}=\frac{\mathrm{E}_{1}-\mathrm{E}_{\mathrm{c}}^{0}}{0.05916}
$$

This scale is obviously based on Sbrensen's original definition of pH in terms of concentration as

$$
\mathrm{pH} \equiv \log \frac{1}{c_{\mathrm{H}^{+}}}
$$

With the introduction of the concept of activity (Lewis, 1913; Lewis and Randa11, 1923), $\mathrm{pH}$ was redefined as (S6rensen and Linderstrom-Lang, 1924)

$$
\mathrm{pH} \equiv \log \frac{1}{a_{H^{+}}}=-\log a_{H^{+}}=-\log \left(m_{H^{+}}+\gamma_{H^{+}}\right),
$$

where $\mathrm{m}_{\mathrm{H}^{+}}$and $\gamma_{\mathrm{H}^{+}}$represent the molality and activity coefficient of $\mathrm{H}^{+}(\mathrm{ag})$. With the recognition that galvanic cell e.m.f.'s respond to activities, at $25^{\circ} \mathrm{C}$

$$
\mathrm{pH}=\frac{\mathrm{E}-\mathrm{E}_{\mathrm{a}}^{\circ}}{0.05916}
$$

The constants $E_{c}^{0}$ and $E_{a}^{0}$ have slightly different numerical values, and Bates (1973) points out that

$$
\mathrm{pH}_{\mathrm{a}} \cong \mathrm{pH}_{\mathrm{c}}+0.04
$$

where $\mathrm{pH}_{c}$ and $\mathrm{pH}_{\mathrm{a}}$ refer to the $\mathrm{pH}$ scales of equations (3) and (6) respectively. The uncertainty of $\sim 0.04 \mathrm{pH}$ units reflects the uncertainties in the extra thermodynamic assumptions involved in attempting to define liquid junction potentials and individual ion activity coefficients. From these early beginnings eventually evolved the realization that for most practical purposes,

$1 /$

$E_{C}^{O}$ is used here simply to represent a standard e.m.f. on a concentration scale; this term is in fact more complex than represented here (see Bates, 1973, chap. 2).

$2 /$

As with $E_{c}^{O}, E_{a}^{o}$ is a simplified term referring to a standard e.m.f. (see Bates, 1973, Ch. 2). 
the fundamental aspects of solution theory have little numerical impact on $\mathrm{pH}$ measurement, leading to the operational definition of $\mathrm{pH}$ now recommended (see Bates, 1973, p. 29)

$$
\mathrm{pH}(\mathrm{X})=\mathrm{pH}(\mathrm{S})+\frac{\left(E_{\mathrm{X}}-E_{\mathrm{S}}\right) \mathrm{F}}{2.303 R T},
$$

with $\mathrm{pH}(\mathrm{X})$ as the unknown $\mathrm{pH}$, and $\mathrm{pH}(\mathrm{S})$ the assigned $\mathrm{pH}$ value of a standard.

$$
\text { Definition of } p \varepsilon
$$

Jørgensen (1945, p. 9) states that "...thermodynamics gives the completely analogous expression that

$$
\text { Eredox electrode }_{\text {re }}=0.0001983 \mathrm{~T} \log \left[c_{\text {electron }} / C\right],
$$

where $C$ is a constant...." $1 /$. J $\phi$ rgensen correctly points out that equation (9) refers to the potential difference across a single interface, which is unmeasurable, and that the redox electrode must be combined with a reference electrode in order to make an e.m.f. measurement possible. If the reference electrode is the Standard Hydrogen Electrode (S.H.E.), the e.m.f. is termed Eh, and Jorgensen defines the parameter

$$
\mathrm{p} \varepsilon=\mathrm{Eh} / 0.0001983 \mathrm{~T}
$$

Keeping in mind that Eh is in fact a measurement relative to $\mathrm{E}^{\circ} \mathrm{SHE}$, this definition is (at $25^{\circ} \mathrm{C}$ )

$$
\mathrm{p} \varepsilon=\mathrm{Eh} / 0.05916
$$

Note that this is totally analogous to Sorensen's original definition of $\mathrm{pH}$ given by equation (3), except that Eh now refers to a "redox electrode" paired with the S.H.E., rather than the $\mathrm{pH}$ electrode in equation (3).2/ Jorgensen then states "The expression of $\mathrm{p} \varepsilon$ is completely analogous to $\mathrm{pH}$. ", and "The expression $p \varepsilon$ can be said to be an expression for the negative logarithm of the electron concentration...". This definition, in equation form, is

$$
p \varepsilon \equiv-\log \text { celectron }
$$

\footnotetext{
$1 /$ J $\phi$ rgensen (1945); translation by U.S. Joint Publications Research

Service. This equation is in fact based on derivations by Clark (1928, p.377); although this equation is not specifically attributed to Clark, Jorgensen does cite Clark's work abundantly.

2/

Jørgensen does not claim originality for this concept - he cites M $\phi 1$ ler (1936) and Bronsted (1943, p. 384) for equivalent concepts - the "redox exponent."
} 
The various facts and assumptions involved in the definition of $\mathrm{pH}$ are compared below with the corresponding concepts in the definition of $p \varepsilon$ (summarized in table 1).

Table 1. The pe-pH Analogy (?) .

1. $\mathrm{H}^{+}$(aq) concentrations $>0$.

2. Electrodes respond to $\mathrm{H}^{+}$(aq) from solutes and solvent.

3. $\mathrm{H}_{2(\mathrm{~g})}=2 \mathrm{H}^{+}(\mathrm{aq})+2 \mathrm{e}^{-}(\mathrm{Pt})$ approaches reversibility.

4. $10^{-15}<\mathrm{m}_{\mathrm{H}^{+}}{ }_{(\mathrm{aq})}<10$

5. In pure water, $\mathrm{pH} \sim 7$;

$\mathrm{m}_{\mathrm{H}^{+}}{ }_{\mathrm{aq})} \cong 10^{-7}$

6. $\mathrm{H}^{+}(\mathrm{aq})$ is a weak oxidizing agent; it can be reduced to $\mathrm{H}_{2}$ (g) in aqueous solution.
1. $\mathrm{e}^{-}$(aq) concentrations $\cong 0$.

2. Electrodes respond to electron transfer from solutes.

3. $\operatorname{Red}_{(a q)}=0 x_{(a q)}+e^{-}(p t)$ is generally irreversible.

4. $\mathrm{m}_{\mathrm{e}^{-}}$(aq) $\cong 0$;

$10^{-65}<a_{e^{-}}<10^{-35}$

5. In pure water, $p \varepsilon \sim 5.9$; $\mathrm{pe}^{-}$(aq) $\sim 55$.

6. $\mathrm{e}^{-}(\mathrm{aq})$, once formed, is a stronger reducing agent than metallic sodium. 
1. The $\mathrm{pH}$ definition is based on observable concentrations of hydrogen ions, based on measurements of physically real quantities - salt and HCl concentrations and measured ionic conductivities. The definition of $p \varepsilon$ on the other hand is used to invoke the existence of electron concentrations. Here Jorgensen's lack of concern over concentration vs. activity is gravely in error. As will be shown later, $1 /$ the equilibrium concentration of aqueous electrons is essentially zero; thus, from the viewpoint of reaction mechanism, the distinction between activity and concentration is crucial. This was clearly recognized by Clark (1928); implications are discussed in more detail later in this paper.

2. The various $\mathrm{pH}$ electrodes unquestionably respond in a general way to aqueous hydrogen ions.2/ Since aqueous hydrated electrons do not exist at equilibrium, the redox electrode must respond to electrons produced by reacting solutes.

3. This raises serious concern regarding the reversibility of the electrode reaction. This reversibility is necessary in order for the definition of $\mathrm{p} \varepsilon$ in equations (10) and (11) to be valid. For many natural reactions, this reversibility is not achieved. This is a crucial requirement because if the electrode reaction is not reversible, the relation

$$
E=\frac{\Delta G_{\text {reaction }}}{n F}
$$

will not hold for measured e.m.f.'s. That is, an e.m.f. can be calculated that should exist if the cell reaction were reversible, but if reversibility is not experimentally achieved the measured e.m.f. will bear no relation to $\Delta G_{\text {reaction }}$

4. Hydrogen ions in aqueous solutions exist over a range of physically meaningful concentrations, ranging from about $10 \mathrm{~m}$ to $10^{-15} \mathrm{~m}$. Equilibrium concentrations of hydrated electrons are practically zero; activities range from $10^{-35}$ to $10^{-65}$ under conditions attained in most natural waters (see fig. 2 discussed later in text).

5. In aqueous solutions, $\mathrm{H}^{+}(\mathrm{aq})$ is donated by the solvent, water. This condition also is not met for redox reactions; as already stated, $\mathrm{m}_{\mathrm{e}^{-}}(\mathrm{aq}) \cong 0$. Hydrated electrons are formed at electrodes only under exceptional circumstances. A $p \varepsilon$ can be calculated, but not measured, for the pure solvent in aqueous solutions - water. (This will also be discussed later in this paper).

1/

Although the necessary data were not available, this concept is implicit in Clark's entire discussion of electron activity.

$2 /$

The specific chemical nature of the hydrated proton is still incompletely understood; it is referred to in this paper as $\mathrm{H}^{+}(\mathrm{aq})$, or occasionally as $\mathrm{H}_{3} \mathrm{O}^{+}$. 
Thus, the sequence of conceptual development of $\mathrm{pH}$ began with direct chemical observation, proceeded through measurements of electrochemical cells, and led to the definition of $\mathrm{pH}$ scales based on measured e.m.f.'s. However, in the case of the $p \varepsilon$ parameter, J $\phi r g e n s e n$ began with an equation based on an analogy with the $p H$ definition, defined the $p \varepsilon$ parameter, and postulated the existence of electron activity or concentration. Although there was no body of knowledge concerning aqueous electrons at that time (1945), the concept of electron activity had been previously discussed in detail by Clark $(1922,1928)$. Before pursuing this topic, however, two additional concepts must be introduced: (a) the electrochemical potential, and (b) the relation between redox potentials and electrostatic potentials.

\section{Potential Differences Across One (or less) Interfaces}

To this point, only systems of coupled interfaces have been considered, with the stipulation that reversibility is necessary for equation (13) to hold. The fact that the electrical potentials in metals and those in electrolyte solutions cannot be considered identical entities was recognized from the time of Gibbs. Clark (1928, pp. 379-380) discussed the problem in some detail in connection with the electron activity, but it was not until the work of Bronsted (1929) and Guggenheim $(1929,1930)$ that the concepts were formalized as the electrochemical potential.

\section{The Electrochemica1 Potential}

Although potential differences across single interfaces cannot be measured, equations for various equilibrium criteria can be formulated in terms of electrical and/or chemical effects. These equations provide further insight into the nature of the electron activity concept and the limitations of the pe parameter.

Consider the following example (similar derivations can be found in some recent physical chemistry texts). A platinum wire (assumed to be absolutely inert chemically whose only function is to act as a source/sink for electrons) is immersed in an aqueous solytion equimola (assume $\mathrm{m}_{1}=1 \mathrm{mmol} / \mathrm{kg}$ for $\mathrm{Fe}^{2+}(\mathrm{aq})$ and $\mathrm{Fe}^{3+}(\mathrm{aq})$ ). Further assume that before the two phases come in contact they are both absolutely electrically neutral. When the two phases are brought into contact, transfer of conducting electrons in the platinum electrode to or from the solutes in the aqueous phase will occur.

Assume that in this case the reaction that occurs is

$$
\mathrm{Fe}^{3+}(\mathrm{aq})+\mathrm{e}^{-}(\mathrm{Pt})+\mathrm{Fe}^{2+}(\mathrm{aq})
$$

As reaction (14) proceeds, the platinum will acquire a net positive charge through loss of electrons, and the aquequs phase will acquire a net negative charge through conversion of $\mathrm{Fe}^{3+}$ to $\mathrm{Fe}^{2+}$ while $\mathrm{m}_{\mathrm{Cl}}^{-}$(aq) remains constant. 
Reaction (14) wil1 proceed until the potential difference $\left(\Phi_{(\mathrm{Pt})}-\Phi_{(\mathrm{aq})}\right)^{1 /}$ becomes sufficiently great that the electrical work necessary to overcome the potential difference and extract electrons from the platinum exactly balances the chemical energy that is gained from the conversion $\mathrm{Fe}^{3+}$ (aq) to $\mathrm{Fe}^{2+}$ (aq) Reaction (14) has then achieved equilibrium:

$$
\mathrm{Fe}^{3+}(\mathrm{aq})+\mathrm{e}^{-}(\mathrm{Pt})=\mathrm{Fe}^{2+}(\mathrm{aq})
$$

Assume for the remainder of this example that reaction (15) occurs reversibly at the platinum electrode surface.

The fact that electrical work needs to be considered in formulating criteria for equilibrium among phases of different electrical potentials was recognized by Gibbs and all subsequent major authors in the field of electrochemistry. Bronsted (1929) and Guggenheim (1929, 1930) defined the electrochemical potential as

$$
\bar{\mu}_{i}=\mu_{i}+z_{i} F \Phi_{i},
$$

where:

$$
\begin{aligned}
& \bar{\mu}_{i}=\text { electrochemical potential of } i \\
& \mu_{i}=\text { chemical potential of } 1 \\
& z_{i}=\text { electrical charge on } i \\
& F=\text { Faraday constant, and } \\
& \Phi_{1}=\text { electrical potential of the phase } \\
& \text { containing } 1 .
\end{aligned}
$$

At equilibrium represented by reaction (15), the following relation holds (see Guggenheim, 1929):

$$
\bar{\mu}_{\mathrm{Fe}^{2+}}{ }_{(\mathrm{aq})}=\bar{\mu}_{\mathrm{Fe}}{ }^{3+}(\mathrm{aq})+\bar{\mu}_{\mathrm{e}}{ }_{(\mathrm{Pt})}
$$

Introducing (16) (with $\mathrm{Z}_{\mathrm{e}^{-}}=-1$ ) and rearranging, yields

$$
\mathrm{F \Phi}(\mathrm{Pt})-\mathrm{F \Phi}(\mathrm{aq})=\mu_{\mathrm{Fe}}{ }^{3+}(\mathrm{aq}){ }^{-} \mu_{\mathrm{Fe}}{ }^{2+}(\mathrm{aq})+\mu_{\mathrm{e}^{-}}(\mathrm{Pt})
$$

$1 /$

The Galvani, or inner, potentials. 
Introducing the relation $\mu_{i}=\mu_{i}^{0}+2.303 R T \log a_{i}$ and rearranging, gives

$$
\begin{aligned}
& \Phi(P t)-\Phi_{(a q)}=\frac{1}{F}\left(\mu^{\circ} \mathrm{Fe}_{(\mathrm{aq})}^{3+} \mu^{\circ} \mathrm{Fe}^{2+}(\mathrm{aq})\right. \\
& +\frac{2.303 \mathrm{RT}}{\mathrm{F}} \log \frac{\mathrm{a}_{\mathrm{Fe}}{ }^{3+}(\mathrm{aq})}{\mathrm{a}_{\mathrm{Fe}}{ }^{2+}(\mathrm{aq})}+\frac{\mu_{\mathrm{e}^{-}(\mathrm{Pt})}}{\mathrm{F}}
\end{aligned}
$$

Note that with $\mu_{e^{-}(P t)}=0^{1 /}$ and appropriate numerical conversions of free energies to e.m.f.'s, equation (19) reduces to the Nernst equation for the $\mathrm{Fe}^{2+}-$ $\mathrm{Fe}^{3+}$ half-cell. Note also that both the electrode and the aqueous phase are left with a net electric charge (assumed positive for the electrode and negative for the solution), thus appearing to violate one of the fundamental tenets of solution chemistry, that of electrical neutrality. The question of electrical neutrality, or its lack, is linked to the separation of the electrochemical potential into a "chemical" and an "electrical" term in equation (16) $2 /$ This separation rests ultimately on the observation that electrical potentials generated by chemical reactions are never in excess of about $\pm 3 \mathrm{~V}$. As pointed out by Guggenheim (1949), electrostatics shows that voltages of this magnitude are generated by surface charge densities on the order of $10^{6}$ electrons $/ \mathrm{cm}^{2}$.

For purposes of example (adapted from Guggenheim, 1949, p. 331), consider a 1 -gm spherical $\mathrm{Pt}$ electrode in a 1 iter beaker with an $\mathrm{Fe}^{3+} / \mathrm{Fe}^{2+}$ solution as discussed earlier. As $\mathrm{Fe}^{3+}$ (aq) is converted to $\mathrm{Fe}^{2+}$ (aq) via equation (16) to a potential difference of $\sim 1 v, 3 /$ the solution will have a net excess $\mathrm{C1}^{-}(\mathrm{ag})$ concentration of $2 \times 10^{6}$ ions of $\mathrm{Cl}^{-}$(aq) per $\mathrm{Kg} \mathrm{H}_{2} \mathrm{O}$, or an excess molality of $\mathrm{Cl}^{-}(\mathrm{aq})$ of $\sim^{3} \times 10^{-18}$. The excess of $\mathrm{Pt}^{4+}$ remaining in the electrode would be $\sim 7.5 \times 10^{-19}$ moles $/ \mathrm{gm}$, equivalent to a deficit of $\sim 4 \times 10^{6}$ electrons $/ \mathrm{cm}^{2}$ at the electrode surface. Although these quantities of charge are sufficient to give rise to measurable electrical potential differences, in terms of the bulk chemistry of the two phases they are totally insignificant relative to the $10^{-3}$ molal chloride present in the solution and the $\sim 5 \times 10^{-} 3 \mathrm{~g}$-atom of $\mathrm{Pt}$ in

1/ This convention is discussed later in this paper

$2 /$ The fact that this assumption is arbitrary was recognized by Gibbs (see Guggenheim, 1929).

$3 /$

An assumption; the actual potential difference across a single interface cannot be measured. 
the electrode. Thus the separation of the electrochemical potential into a chemical term and an electrical term is based on the extra-thermodynamic assumption that the changes in concentration associated with charge development across the interface are, in the bulk phases, negligible relative to presently available analytical techniques. Therefore, from a practical stand point, changes in the electrical potential of the aqueous and metaliic phases take place at constant composition, and it is in fact reasonable to deal with these on a separate basis, i.e., as in equation (16):

$$
\bar{\mu}_{i}=\mu_{i}+z_{i} F \Phi_{i}
$$

\section{Redox Potentials and Electrostatic Potentials}

Another question that must be addressed is the relationship between electrostatic potential and redox potential. When the e.m.f. of an electrochemical cell. is being measured ( $\mathrm{fig} .1$ ), a true difference in electrostatic potential exists in the wires (of the same metal) across which the potential difference is being measured. This potential difference reflects the difference in the tendency of the two half-cells to transfer electrons to or from metal electrodes. However, as long as the junction between the sample solution and reference electrode solution functions with a junction potential of zero, the electrical potential, $\Phi$, of the two aqueous phases will be equal, although the numerical value of this potential on an absolute scale is unknown. To compare this electrostatic potential with the redox potential of an electrolyte solution consider the following example.

A solution is made up of equal amounts of $\mathrm{FeCl}_{2}$ and $\mathrm{FeCl}_{3}$, and contains no excess whatsoever of cations or anions - that is, the solution initially exhibits absolute electroneutrality. The measured e.m.f. of a platinum electrode in this solution relative to the S.H.E. would be about +0.77 volt; the solution would be termed geochemically an "oxidizing" solution. Now assume that hydrogen is bubbled through the solution, and reaction (20)

$$
\mathrm{Fe}^{3+}(\mathrm{aq})+\frac{1}{2} \mathrm{H}_{2(\mathrm{~g})} \rightarrow \mathrm{Fe}^{2+}(\mathrm{aq})+\mathrm{H}^{+}(\mathrm{aq})
$$

continues until essentially all of the $\mathrm{Fe}^{3+}$ (aq) has been converted to $\mathrm{Fe}^{2+}$ (aq) The solution now consists of a solution of dissolved $\mathrm{FeCl}_{2}, \mathrm{HCl}$, and $\mathrm{H}_{2}(\mathrm{~g})$, whose e.m.f. relative to the S.H.E. will be negative for $\mathrm{pH}^{\prime}$ s greater than zero. The solution now is a "reducing" one - its redox potential relative to the initial solution has changed dramatically. Electrostatically, however, the solution is still absolutely neutral; only neutral molecules have been added to it, and every $\mathrm{Fe}^{3+}$ ion has been replaced by a combination of one $\mathrm{Fe}^{2+}$ and one $\mathrm{H}^{+}$ions. From a similar argument, Clark (1928, p. 374) concluded that "We are evidently not concerned with ordinary, electrostatic affairs." 


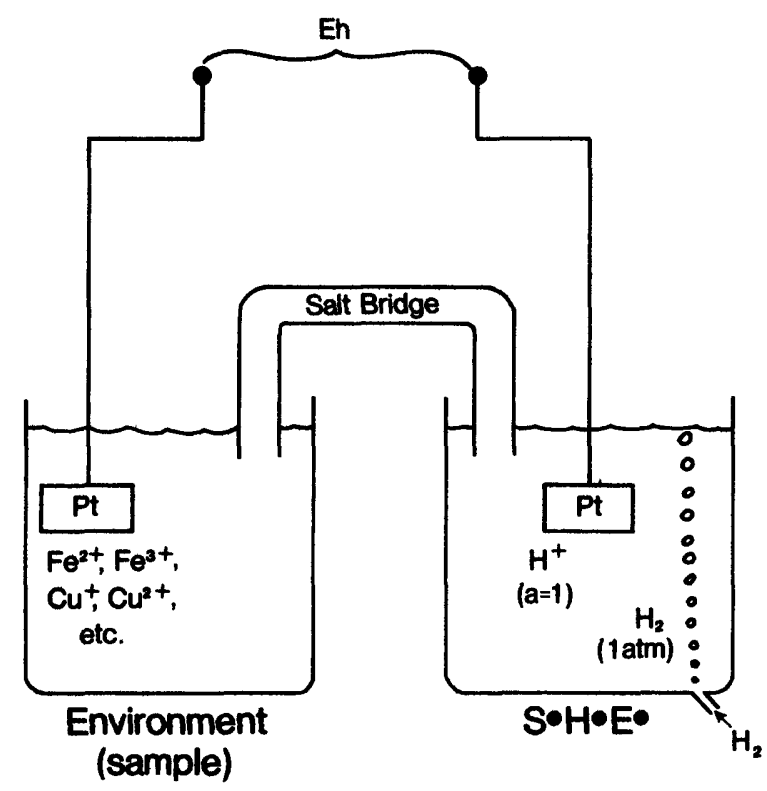

Figure 1. Schematic representation of an Eh measurement. S.H.E. refers to the stand ard hydrogen electrode. If the liquid junction across the salt bridge is zero, the electrical potentials of the sample and the S.H.E. are the same, regardless of the measured voltage across the electrodes; that is, regadless of the Eh of the sample. 
The following discussion is closely adapted from W. M. Clark $(1922,1928)$ who used the following formulation for a general half-cell reaction in the aqueous phase in which "A pressure of free electrons may be postulated...",1/

$$
\operatorname{RED}_{(a q)}=0 x^{n+}(a q)+n e^{-}(a q)
$$

for which an equilibrium constant can be written

$$
K=\frac{a^{n} e^{-}(a q) a^{a^{n+}} o x_{(a q)}}{a_{R E D}(a q)}
$$

Using the $\mathrm{Fe}^{2+}-\mathrm{Fe}^{3+}$ couple as a specific example, (21) becomes

$$
\mathrm{Fe}^{2+}(\mathrm{aq})=\mathrm{Fe}^{3+}(\mathrm{aq})+\mathrm{e}^{-}(\mathrm{aq}) \cdot^{2 /}
$$

Clark (1928, p. 375) pointed out that in the system $\mathrm{Fe}^{3+}(\mathrm{aq})-\mathrm{Fe}^{2+}(\mathrm{aq})$ coupled to a hydrogen electrode (fig. 1), for the hypothetical transfer (viaconnected electrodes) of one faraday of aqueous eleçtrons from the solution in a hydrogen electrode (HE) to a sample solution of $\mathrm{Fe}^{3+}$ (aq) and $\mathrm{Fe}^{2+}$ (aq),

$$
-\Delta G=E F=R T \ln \frac{a_{e^{-}}(H E)}{a_{e^{-}(F e)}} \text {, }
$$

where $a_{e}$-represents the activity of aqueous electrons. Wi thout thermochemical data on $\mathrm{e}^{-}$(aq) this equation represents all that can be rigorously stated relating e.m.f.'s to electron activities in aqueous solutions, namely, that a measured e.m.f. is proportional to the ratio of electron activities in two solutions, provided that all electron transfer reactions are reversible.

$\underline{1}$

C1ark, 1928, p. 273.

2/

Note that this is not identical to reaction (15) 
By the 1960's preliminary data were available for hydrated electron free energies. Even these data show that, at equilibrium, hydrated electrons cannot exist at physically meaningful concentrations - a fact recognized by Truesdell (1968). A very considerable literature on solvated electrons has developed over the last two decades (see Hart and Anbar, 1970; Hostettler, 1983). The following information on the hydrated electron is taken from Hostettler (1983).

It is possible to synthesize very dilute (micromolar and less) solutions of aqueous electrons, $\bar{e}_{(\mathrm{aq})}$, by means of very intense pulses of radiation. Once formed, $e^{-}(\mathrm{aq})$ reacts very rapidly. (with a half-life of $230 \mu \mathrm{s}$ ) wi th surrounding water molecules to produce $\mathrm{H}_{(\mathrm{aq})} \mathrm{radicals}$ and ultimately $\mathrm{H}_{2}(\mathrm{~g})$ and $\mathrm{OH}^{-}(\mathrm{aq}) \cdot$ The pertinent data for this discussion are those permitting construction of a thermodynamic cycle to calculate the reaction free energy

$$
\mathrm{e}^{-}(\mathrm{aq})+\mathrm{H}^{+}(\mathrm{aq})=\frac{1}{2} \mathrm{H}_{2(\mathrm{~g})} ; \Delta \mathrm{G}_{\text {reaction }}=-66.3 \mathrm{kcal} \mathrm{mol}^{-1} ;^{1 /}
$$

from which the standard free energy of formation of the aqueous electron is

$$
\mu^{0} \mathrm{e}_{(\mathrm{aq})}^{-}=66.3 \mathrm{kcal} \mathrm{mol}^{-1}
$$

This is a critical number in determining the physical nature of the parameter as related to hydrated electrons.

At this point the necessary information is available to allow a discussion of electrochemical conventions and the relation between $\mathrm{E} h$, the activity of aqueous electrons, and the pe parameter.

Baxendale (1964) calculated $\Delta G_{r}=-63.9 \mathrm{kcal} / \mathrm{mole}$; recalculated as $\Delta G_{r}$ $=-66.3 \mathrm{kcal} / \mathrm{mole}$ by Hostettler (1983) using data from Jortner and Noyes (1966); also see di scussion in Hart and Anbar (1970, p. 63). 


\section{Electrochemical Conventions: Eh, pe, and Electron Activity}

The convention of separating the chemical and electrical contributions to the electrochemical potential assumes that changes in $\bar{\mu}$ electron in a conducting metal are due only to changes in electrical potential, $\Phi(m)$. The chemical potential of electrons in conducting metals is thus assumed to be constant. Therefore in a platinum electrode, $\mu_{e^{-}}^{-}(\mathrm{Pt}) \equiv$ constant, which in turn implies that $a_{e^{-}}(P t) \equiv$ constant. $^{1 /}$ This is an important conclusion, since it immediately shows that the pe parameter cannot be related to the chemical activity of electrode electrons.

The relationship between electrode electrons and aqueous electron activity can be derived as follows. For reaction (23), at equilibrium

$$
\mu_{\mathrm{Fe}^{3+}}{ }_{(\mathrm{aq})}^{-} \mu_{\mathrm{Fe}^{2+}}{ }^{2+(\mathrm{aq})}=-\mu_{\mathrm{e}^{-}}^{-}(\mathrm{aq})
$$

The link with electrode electrons is provided by equation (18), which rearranges to

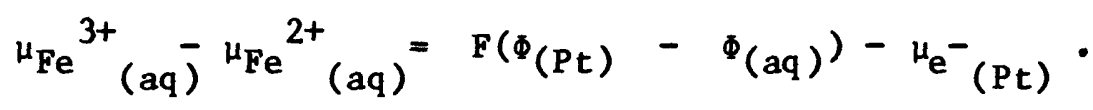

From (27) and (28)

$$
F(\Phi(P t)-\Phi(a q))=\mu_{e^{-}}{ }_{(P t)}^{-} \mu_{e^{-}}{ }_{(a q)} \dot{2}^{\prime}
$$

1/ This is consistent with C1ark's (1922) original convention that the electron activity in metals is constant. No convention regarding electrons in metals is provided by International Union of Pure and Applied Chemistry (1970); the convention of zero chemical potential for electrons in metals can be found in some physical chemistry textbooks, for example Castellan 1970, p. 387;

$\underline{2}$ Bockris and Reddy, 1970, pp. 900-901.

The same result is obtained simply by equating $\bar{\mu}_{e^{-}}{ }_{(P t)}=\bar{\mu}_{e^{-}}(a q)$. 
Equation (29) is general; its application in the Standard Hydrogen Electrode (S.H.E.) is the basis for several electrochemical conventions.

In the S.H.E.

$$
F\left[\Phi_{(P t)}-\Phi_{(a q)}\right]_{\text {SHE }}=\left[\mu_{e^{-}}(P t)^{-} \mu_{e^{-}}(a q)\right]_{S H E}
$$

The potential difference represented by the left side of equation (30) is a change in potential across a single interface, and thus inherently unmeasurable. By convention, this potential difference is assigned a value of zero:

$$
[\Phi(P t)-\Phi(a q)]_{\text {SHE }} \equiv 0
$$

This is the defined e.m.f. of the standard hydrogen half-cel1. Therefore, from (30) and (31),

$$
\left[\mu_{e}^{-}(P t)-\mu_{e}^{-}(a q)\right]_{S H E}=0
$$

In (32), only the difference in chemical potentials must equal zero; the numerical values are arbitrary. The chemical potential of electrons in $P t$ may thus be assigned a value of zero:

$$
\mu_{e^{-}}^{-}(P t, S H E) \equiv 0
$$

Because the chemical potential of electrons in conducting metals is taken to be constant, (33) generalizes to

$$
\mu_{e^{-}}^{-} \equiv 0
$$

Therefore, from (32)

$$
\mu_{\mathrm{e}^{-}}{ }_{(\mathrm{aq}, \mathrm{SHE})} \equiv 0
$$


However, unlike metal electrons, the chemical potential of aqueous electrons is defined equal to zero only in the S.H.E. Under other conditions, in general

$$
\mu_{\mathrm{e}^{-}}^{-} \neq 0
$$

As shown in the above discussion, the major thermodynamic developments necessary for the treatment of equilibrium electrochemistry and electron activity were complete by about 1930; in $1945 \mathrm{~J} \phi$ rgenson defined p $\varepsilon$. Following this, Sillen (1952) urged the use of $p \varepsilon$ and in a later paper (Sillen, 1967), provided major impetus for 1 ts use in geochemistry.

In each of these papers, Sillen makes a crucial postulate, illustrated by the following quotation (Sillen, 1967, p. 52)

"In oxidation-reduction equilibria, the common reagent is the electron, $e^{-}$, and matters are simplified considerably if one treats the electron like any other reagent, $\mathrm{H}^{+}, \mathrm{Ag}^{+}, \mathrm{Cl}^{-}$, etc. (Note that neither of these exists free and unhydrated in aqueous solutions)."

An assumption implicit in this statement is that although free anions and cations (particularly $\mathrm{H}^{+}$) $1 /$ do not exist in aqueous solutions, hydrated anions and cations are present.2/ Also implicit in Sillen's statement, however, is the assumption that although free electrons do not exist, hydrated electrons do. The then available data demonstrate this premise to be false (cf. Truesde11, 1968).

Sillen's statement that the electron should be treated as any other reagent is based on the fact that by so doing, the form of the resulting equations involving electron activity and $p \varepsilon$ is mathematically analogous to equivalent equations for $\mathrm{pH}$ (see Stumm and Morgan, 1981, table 7-2). This is, however, a mathematical - not chemical - analogy between the defined variables pH and $p \varepsilon$, and is thermodynamically valld only for equilibrlum systems. The earlier comparison of some of the chemical properties of $\mathrm{H}^{+}$(aq) and $\mathrm{e}^{-}$(aq) summarized in table 1, shows that from a chemical viewpoint, the two specles are very dissimilar, as are their reactions in natural waters.

The formal relationships between $\mathrm{Eh}, \mathrm{p} \varepsilon$, and $\mathrm{a}_{\mathrm{e}^{-}}{ }_{(\mathrm{aq})^{\text {, can }}}$ be summarized as follows. With conventions (34) and (35), equation (29) becomes (relative to the S.H.E., )

$$
F\left[\Phi_{(P t)}-\Phi(a q)\right]=-\mu_{e}^{-}(a q)
$$

I/ (Kolthoff, 1930) cites $\mathrm{K}=10^{-130}$ for dissociation of $\mathrm{H}_{3} \mathrm{O}^{+}$to $\mathrm{H}_{2} \mathrm{O}$ and $\mathrm{H}^{+}$). For a more recent discussion, see Giguere (1999).

2/ All of the classical experiments of physical chemistry lead to the conclusion that hydrated ions, including $\mathrm{H}^{+}$(aq) do exist. 
Introducing the definition of chemical potential,

$$
\mu_{e^{-}}=\mu^{\circ} e_{(a q)}^{-}+2.303 R T \log a_{e^{-}}+\text {aq) }
$$

yield s

$$
-\log a_{e_{(a q)}^{-}}=\frac{F}{2.303 R T} E h-\frac{\mu^{\circ} e^{-}(a q)}{2.303 R T} \text {. }
$$

With the definition

$$
\mathrm{pe}^{-}(\mathrm{aq}) \equiv-\log \mathrm{a}_{\mathrm{e}^{-}(\mathrm{aq})},
$$

and with

$$
\mu^{\circ} \mathrm{e}_{(\mathrm{aq})}^{-}=+66.3 \mathrm{kcal} / \mathrm{mol},
$$

equation (38) gives

$$
\mathrm{pe}^{-}(\mathrm{aq})=\frac{\mathrm{F}}{2.303 \mathrm{RT}} \mathrm{Eh}+48.6 \text {. }
$$

With Jorgensen's initial definition of $p \varepsilon=E h(F / 2.303 R T)$, equation (40) becomes

$$
\mathrm{pe}^{-}(\mathrm{aq})=\mathrm{p} \varepsilon+48.6
$$

Equations (38, (40), and (41) express the numerical relationship between the equilibrium activity of aqueous electrons and the $p \varepsilon$ parameter as currently used. Figure 2 shows that in natural waters, at equilibrium, concentrations of aqueous electrons can never achieve physically meaningful values. 
Equation (38) explains much of the ambiguity associated with the pe parameter. Equation (38) shows that in order for the two definitions of $p \varepsilon(p \varepsilon=(F / 2.303 R T) E h$ and $p \varepsilon=-\log a_{e^{-}}(a q)$ to hold simultaneously, $\mu^{\circ} \mathrm{e}^{-}$(aq) must be defined as zero:

$$
p \varepsilon=\frac{F}{2.303 R T} \text { Eh, }
$$

and

$$
p \varepsilon=-\log a_{e^{-}}(a q)
$$

if

$$
\mu^{0} \mathrm{e}^{-}(\mathrm{aq}) \equiv 0
$$

However, this convention cannot be quantitatively applied because the numerical reference scale for e.m.f. measurements and free energy values for aqueous ions is already established by the convention of equation (42):

$$
\mu^{\circ} \mathrm{H}^{+}(\mathrm{aq}) \equiv 0
$$

In spite of equations (34),(35), and (42), various authors have applied additional conventions to the S.H.E.. Clark (1928), in the absence of experimental data on $\mathrm{e}^{-}(\mathrm{aq})$, stipulated that $\mathrm{a}_{\mathrm{e}^{-}}^{-}(\mathrm{aq}, \mathrm{SHE}) \equiv 1$ although he did not formally define (through (35)) the standard free energy of aqueous electrons as zero.

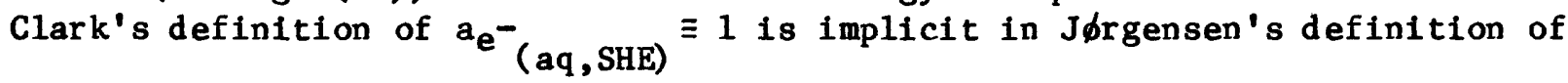
the pe parameter. Sillen (1952, p. 608) states that " $\ldots$. p $\varepsilon=-10 g a_{e}-$ is a measure of electron activity in the solution, choosing the hydrogen-saturated solution of the standard hydrogen electrode as the standard state for $e^{-. " ~ T h e ~}$ most frequently observed treatment (for example, see Stumm and Morgan, 1981, p. 422-423) of the S.H.E. conventions is the assignment of zero free energy to the reaction

$$
\frac{1}{2} \mathrm{H}_{2(\mathrm{~g})}=\mathrm{H}^{+}(\mathrm{aq})+\mathrm{e}^{-} ; \Delta \mathrm{G}_{\text {reaction }}^{\circ} \equiv 0 \text {, }
$$

without specifying the physico-chemical state of the electron. 


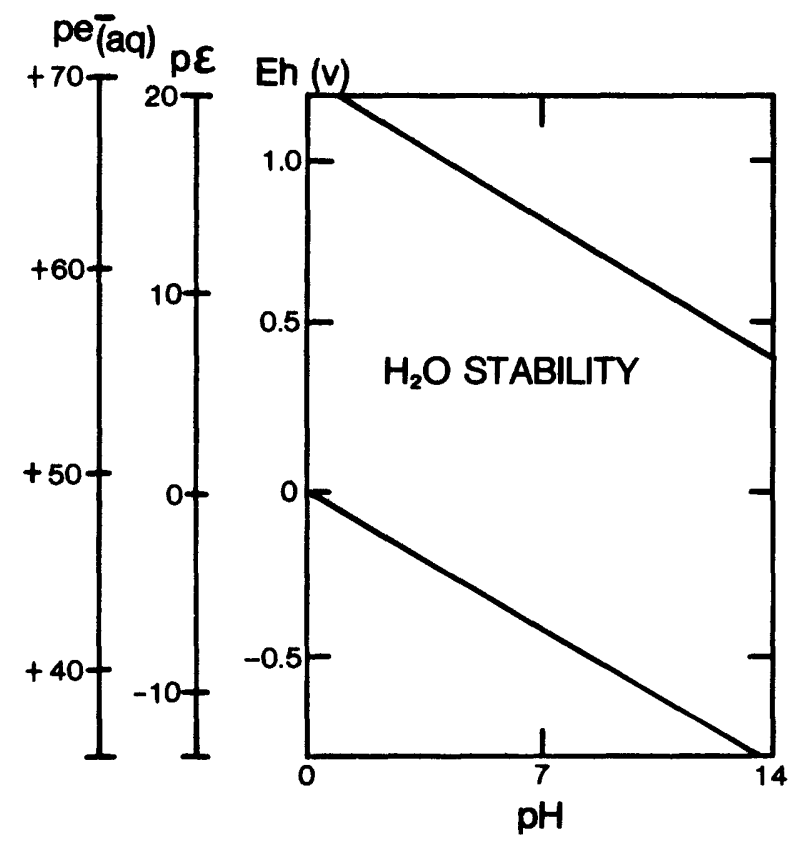

Figure 2. The water stability field presented as a function of $\mathrm{pH}^{\mathrm{v}}$ versus $\mathrm{pe}^{-}$(aq), $p \varepsilon$, and Eh. 
The choice of the S.H.E. as the standard state for aqueous electrons is present, explicitly or implicitly, in all of the above treatments. There is nothing to preclude this choice, but it has a major drawback - namely that, because the standard state for all other ions is infinite dilution (with the free energy scale defined by (42)), electron activity values calculated on the basis of an S.H.E. standard state can be used as relative numbers only; the calculated activities cannot be quantitatively compared with concentrations or activities of other ions in aqueous solution. Finally, the convention represented by (43) is valid only if the electron in question is $\mathrm{e}^{-}(\mathrm{Pt})$; if $\mathrm{e}^{-}$in (43) is considered to represent an aqueous electron the standard state is implicitly defined again as the S.H.E. Leaving the state of the electron in (43) unspecified, however, also leaves the entire framework of calculations based on (43) undefined. If electron activity calculations are to be quantitatively comparable to the activities of other aqueous ions and quantitatively related to thermodynamic e.m.f. calculations, the electron activity calculations must be based on the free energy value given in equation (26) and the thermodynamic relations summarized by equation (38), (40), or (41).

The major points regarding the concept of electron activity have now been presented. A final point that needs emphasis is that Clark recognized from the first that the electron activity was a concept of little physical reality, but was of use as a conceptual organizational tool. In fact, Clark (1928, p. 375) termed the concept of electron activity".... a tentative expedient destined from the first to be eliminated from the final equations." This opinion was not shared by Jфrgensen (1945), who felt that $p \varepsilon$ values would be desirable for expressing redox measurements. Nevertheless, in the portions of his paper dea1ing with measurements (pp. 16-43), Jorgensen used only Eh as a measure of redox potential.

\section{REDOX POTENTIALS IN AQUEOUS GEOCHEMISTRY}

In the study of redox reactions in natural systems, reaction kinetics are almost always a problem, both in terms of reactions occurring within the system, and in terms of reactions at the electrode surface during Eh measurements. However, an understanding of both categories of reaction requires recognition of the fact that there may be thermodynamic problems superimposed on the kinetic problems. It is the author's opinion that many of the difficulties encountered in the study of redox potentials - particularly their measurement in natural systems - are ascribed to reaction kinetics at the electrode surface when the problems are in fact thermodynamic. The emphasis placed on the similarity between the $\mathrm{p} \varepsilon$ and $\mathrm{pH}$ parameters tends to obscure the thermodynamic problems associated with redox reactions in natural waters. The question of defining redox potential values in disequilibrium systems receives mention, but little emphasis in the geochemical literature. The following discussion will, therefore, begin with systems in which, by definition, reaction kinetics are not a problem namely, aqueous environments assumed to be at chemical equilibrium. 
The nature of the problems encountered when dealing with redox reactions, as opposed to acid-base reactions, is particularly well illustrated by calculation of the $\mathrm{pH}$ and redox potential of pure water at $25^{\circ} \mathrm{C}$ and 1 atm total $\mathrm{P}$.

Assume for purposes of calculation that $a_{i}=m_{i}$ for dissolved ionic species; $a_{i}=P_{i}$ for dissolved gases; and the activity of water is unity. The dissociation of water to $\mathrm{H}^{+}(\mathrm{aq})$ and $\mathrm{OH}^{-}(\mathrm{aq})$ can be written

$$
\mathrm{H}_{2} \mathrm{O}_{(1)}=\mathrm{H}_{(\mathrm{aq})}^{+}+\mathrm{OH}_{(\mathrm{aq})}^{-} ; \quad \mathrm{K}=10^{-14} \text {. }
$$

From (44)

$$
\mathrm{a}^{+}{ }_{(\mathrm{aq})}=\mathrm{aOH}^{-}(\mathrm{aq})
$$

and

$$
10^{-14}=\mathrm{a}_{\mathrm{H}^{+}}{ }_{(\mathrm{aq})}
$$

Therefore

$$
\mathrm{a}_{\mathrm{H}}^{+}(\mathrm{aq})=10^{-7}, \text { or } \mathrm{pH}=7 \text {, }
$$

giving the unsurprising result that for pure water the $\mathrm{pH}$ is 7 .

The dissociation of water into $\mathrm{H}_{2}(\mathrm{~g})$ and $\mathrm{O}_{2}(\mathrm{~g})$ can be written

$$
2 \mathrm{H}_{2}{ }^{\mathrm{O}}(1)=\mathrm{O}_{2(\mathrm{~g})}+2 \mathrm{H}_{2(\mathrm{~g})} ; \mathrm{K}=10^{-83.9} \text {. }
$$

From reaction (47), $\quad \mathrm{P}_{\mathrm{O}_{2}(\mathrm{~g})}=\frac{1}{2} \quad \mathrm{P}_{\mathrm{H}_{2(\mathrm{~g})}}$

and, at equilibrium, $\quad \mathrm{P}^{3} \mathrm{H}_{2(\mathrm{~g})}=10^{-83.6}$, 
therefore,

$$
\mathrm{P}_{\mathrm{H}_{2}(\mathrm{~g})} \cong 10^{-27.9} \mathrm{~atm} \text {, and } \mathrm{P}_{\mathrm{O}_{2}(\mathrm{~g})} \cong 10^{-28.2} \mathrm{~atm}
$$

From equation (41), for the reaction

$$
\frac{1}{2} \mathrm{H}_{2(\mathrm{~g})}=\mathrm{H}_{(\mathrm{aq})}^{+}+\mathrm{e}^{-}(\mathrm{aq}), \quad \mathrm{K}=10^{-48.6}
$$

Thus, in pure water,

$$
10^{-48.6}=\frac{\left(10^{-7}\right)\left(\mathrm{a}_{\mathrm{e}^{-}}(\mathrm{aq})\right.}{\left(10^{-27.9}\right)^{1 / 2}}
$$

or

$$
\mathrm{a}_{\mathrm{e}^{-}}(\mathrm{aq})=10^{-54.5} ; \quad \mathrm{pe}^{-}(\mathrm{aq})=54.5 \text {, }
$$

from which

$$
\mathrm{p} \varepsilon \cong+5.9 \text { and } E h \cong+0.35 \text { volt. }
$$

If these results are now considered in terms of molalities rather than activities, taking the gas solubilities into account gives

$$
\begin{aligned}
& \mathrm{m}_{2(\mathrm{aq})}<10^{-30,}, \\
& \mathrm{~m}_{2(\mathrm{aq})}<10^{-30,},
\end{aligned}
$$

and from (52)

$$
\mathrm{m}_{\mathrm{e}^{-}}(\mathrm{aq}) \sim 10^{-54.5}
$$


The preceding calculations show that, in this example both the $\mathrm{pH}$ (eq. 46) and redox potential (eq. 53) are thermodynamically defined numbers. In addition, the $\mathrm{pH}$ of pure water can be measured, although in a dilute, unbuffered solution such as this, the required experimental effort is not trivial. The measurement of redox potential presents a different picture entirely. From equation (54), the concentrations of dissolved $\mathrm{H}_{2}$ and $\mathrm{O}_{2}$ are less than 1 molecule $/ 10^{3} \mathrm{~m}^{3}$; the concentration of aqueous electrons is nonsensical. In order for a redox potential to be measured in pure water, concentrations or activities of one of these three chemical species must be measurable; however, at the calculated concentrations, the measurements defy present known chemical or electrochemical analytical techniques.1/

The lack of physical reality, or measurement ability, does not preclude the rigorous definition and use of a parameter as a variable to describe sytems at thermodynamic equilibrium. Probably the most well-known use of redox potential lies in the abundant literature on potential (as Eh or pe) - pH diagrams as representations of equilibrium relations in aqueous systems (Pourbaix, 1966; Krumbein and Garrels, 1952; Garrels and Christ, 1965; Morris and Stumm, 1967; Sillen, 1967; Truesde11, 1968; Hem, 1970; Stumm and Morgan, 1970, 1981; Thorstenson, 1970; Berner, 1971). These diagrams have provided a major interpretive tool since their introduction to the geochemical literature. The diagrams provide critical information on possible equilibrium assemblages of minerals and coexisting water compositions, and also serve to identify disequilibrium assemblages of minerals and/or aqueous redox couples. The diagrams thus provide a qualitative and sometimes semiquantitative conceptual framework for evaluating sequences of mineral assemblages associated with redox processes and for estimating the direction of reactions in disequilibrium systems.

A great deal of effort has been put into measurement of redox potentials in natural systems (excellent examples are provided by Clark, 1928; ZoBe11, 1946; Baas Becking and others, 1960; Sato, 1960). However, the ability to quantitatively relate the electrode measurements to the equilibrium relations embodied in potential - pH diagrams has been limited. Baas Becking and others (1960), in an encyclopedic compilation and critical discussion of $\mathrm{Eh}-\mathrm{pH}$ measurements in natural systems, state that "..... many of the geologically distinct environments could not be differentiated by their $\mathrm{Eh}-\mathrm{pH}$ characteristics." $Z /$ This is based on the fact that the characteristics of many natural systems do overlap, and that the Eh measurements are of ten irreversible. A third factor also needs to be considered - namely that most natural environments represent disequilibrium systems. Recent work by Lindberg and Runnells (1984) conclusively documents lack of internal redox equilibrium in approximately 700 selected ground water samples for which eH measurements and analytical data for at least one redox couple were available.

\footnotetext{
1/

Lehfeldt, 1899 (cited in Clark, 1922, p. 246) referred to numbers of this magnitude as being sufficiently small to ".... involve the rejection of the entire molecular theory of fluids."

Baas-Becking and others, 1960, p. 246.
} 


\section{Disequilibrium Systems}

\section{Total Disequilibrium}

The term total disequilibrium is used to refer to an hypothetical system in which (1) a series of acid deprotonation reactions

$$
\begin{aligned}
& \mathrm{HX}_{(\mathrm{aq})}=\mathrm{H}_{(\mathrm{aq})}^{+}+\mathrm{X}_{(\mathrm{aq})}^{-}, \\
& \mathrm{HY}_{(\mathrm{aq})}=\mathrm{H}_{(\mathrm{aq})}^{+}+\mathrm{Y}_{(\mathrm{aq})}^{-},
\end{aligned}
$$

do not achieve equilibrium with reactions such as

$$
\mathrm{HY}_{(\mathrm{aq})}+\mathrm{X}_{(\mathrm{aq})}^{-}=\mathrm{HX}_{(\mathrm{aq})}+\mathrm{Y}^{-}(\mathrm{aq})
$$

in the time scale of the experiment (or natural process) considered ${ }^{1 /}$; and

2) it is also assumed that multiple redox couples such as

$$
\begin{aligned}
& M_{(a q)}=M_{(a q)}^{+}+e^{-}(a q), \\
& N_{(a q)}=N_{(a q)}^{+}+e^{-}(a q),
\end{aligned}
$$

maintain disequilibrium for the time scale in question. unequal :

In such a system, $\mathrm{pH}$ values calculated from analytical data would be

$$
\mathrm{pH}_{\mathrm{HX} / \mathrm{X}^{-}} \neq \mathrm{pH}_{\mathrm{HY} / \mathrm{Y}^{-}}
$$

$1 /$ Most protolysis reactions are very rapid; an example of a slow reaction on a laboratory time scale is the uptake of $\mathrm{H}^{+}$during the polymerization of the tungstate ion, $\mathrm{WO}_{4}{ }^{2-}$, to several more complex species (see Baes and Mesmer, 1976, pp. 257-260, for details and references). 
Similarly, for the redox reactions

$$
\mathrm{pe}^{-}(\mathrm{aq}) \mathrm{M} / \mathrm{M}^{+} \neq \mathrm{pe}^{-}(\mathrm{aq}) \mathrm{N} / \mathrm{N}^{+}
$$

Neither the $\mathrm{pH}$ nor the redox potential in this system can be obtained from a knowledge of the concentrations of $\mathrm{HX}, \mathrm{X}^{-}, \mathrm{HY}, \mathrm{Y}^{-}, \mathrm{M}, \mathrm{M}^{+}, \mathrm{N}$, and $\mathrm{N}^{+}$; both $\mathrm{pH}$ and redox potential are undefinable from thermodynamic calculations based on analytical data.

However, because the $\mathrm{pH}$ electrode responds to the presence of $\mathrm{H}^{+}$( $\left.\mathrm{aq}\right)$ (which is also contributed by the solvent, water) the $\mathrm{pH}$ of the total disequilibrium system can still be measured. But, due to the total absence of $\left.\mathrm{e}^{-} \mathrm{aq}\right)$, an Eh measurement can only measure electrical potentials in the metal electrode (relative to the S.H.E.) produced by electron-transfer reactions involving $M, M^{+}, N$, and $N^{+}$at the electrode surface. $1 /$ The result wil1 be a mixed potential (see Morris and Stumm, 1967; Bockris and Reddy, 1970; Stumm and Morgan, 1970, 1981) resulting from disequilibrium reactions. Even if a steady Eh reading is obtained, it cannot be related to $\mathrm{pe}^{-}$(aq), or for that matter to $p \varepsilon$. Thus, in a total disequilibrium system, the redox potential of an aqueous phase is inherently undefinable and unmeasurable.

\section{Partial Equilibrium}

In a system at partial equilibrium, some reactions are occurring sufficiently rapid1y that equilibrium is achieved, whereas the kinetics of other reactions are sufficiently slow that equilibrium is not achieved. Partial equilibrium characterizes essentially all natural environments and is the greatest source of confusion in dealing with redox reactions. The concept and use of $\mathrm{pH}$ in a partial equilibrium system poses less of a problem and w111 be discussed first.

Experience shows that many homogeneous acid-base reactions are rapid enough to achieve equilibrium, but heterogeneous reactions of ten are sufficiently slow that equilibrium is not achieved. The $\mathrm{pH}$ values calculated from multiple $\mathrm{HX}(\mathrm{aq})$ and $\mathrm{X}^{-}$(aq) couples should agree within analytical error, whereas $\mathrm{pH}$ values calculated from the assumption of equilibrium with various silicate minerals, for

$1 /$

The same problem holds for experiments that attempt to equilibrate a small volume of solution containing an electroactive redox couple with a largevolume sample (Breck, 1972). Electron transfer from the sample will depend on the interaction of specific redox couples in the sample with the material of the connecting membrane. 
example, may well yield widely differing values. Thus, a knowledge of reaction kinetics allows calculation of the $\mathrm{pH}$ from analytical data on the fast reactions, although, in a general sense, the pH cannot be calculated solely from thermodynamics and analytical data. The following points are again emphasized:

(1) hydrated protons exist in the aqueous phase in physically real concentrations, and therefore at any point in time a unique value of $\mathrm{pH}$ exists in the aqueous phase, (2) this value can be calculated thermodynamically from speciation data for fast reactions, and (3) the $\mathrm{pH}$ of the aqueous phase is a measurable parameter. In fact, in the vast majority of aqueous geochemical studies, the pH is first measured, and the measured value then used to determine which constituents in the partial equilibrium systems are at equilibrium, and which are not.

other problems arise in dealing with redox reactions. In some natural environments it appears that $\mathrm{Eh}$ measurements are dominated by a single electroactive couple, and that sometimes the measuring electrode approaches or achieves electrochemical equilibrium with this redox couple.l/ This is the point at which most difficulties with interpretation arise. If other redox couples continue to exist at di sequilibrium in the system, the Eh measurement still has not provided a measurement of a unique redox potential. If considered from the electrochemical vi ewpoint, the measurement represents the electrical potential, in the measuring electrode, of electrons resulting from specific interactions of the electroactive species at the electrode surface. An electron activity, or an electrical potential, characteristic of the aqueous phase, has not been defined or measured.

The same dilemma can be posed in terms of a calculated activity of aqueous electrons. Figure 2 shows that the electron activity calculated for any predominant electroactive couple cannot correspond to physically real concentrations

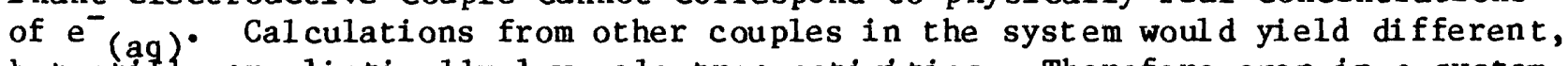
but still unrealistically low, electron activities. Therefore even in a system at partial equilibrium a unique redox potential cannot be measured or defined thermo dynami cally.

Some conclusions can be rigorously stated: (1) If the species concentrations of the dominant electroactive couple are known, and a known amount of a contaminant is introduced that reacts rapidly with the domi nant couple, the final redox states of both can be calculated with available techniques (Helgeson, and others, 1970; Wolery, 1979; Parkhurst, and others, 1980); and (2) if the raction of either or both couples with a platinum electrode is rapid, the final state may be obtained from an Eh measurement.

$1 /$

There is some evidence of Nernstian behavior in water domi nated by Fe (Nordstrom and others, 1979a; Doyle, 1968; Barnes and Back, 1964; Deutsch and others, 1982) waters dominated by Mn (Bricker, 1965), and in sulfur-containing muds (Berner, 1963; Whitfield, 1969; Langmuir and Whittemore, 1971; Boulegue, 1978, Boulegue and Mi chard, 1979). 
Even if these optimistic criteria are met, the electrode measurement is still, in reality, serving only as an anlytical tool providing information on the speciation of the particular redox couple(s) involved; if other couples are still present at di sequilibrium, even in minor or trace amounts, a termodynamic redox potential for the aqueous phase has not been defined or measured.

Examples abound in natural systems in which the two criteria are not met of ten the dominant redox couple(s) will react neither at an electrode surface nor with other chemical species except through the action of microorganisms. The situation can perhaps be best summarized by pointing out the fact that a partial equilibrium system is, at the same time, a partial disequilibrium system, and that the statement of Morris and Stumm (1967, p. 284) that "... the concept of redox potential becaomes meaningless" is still appropriate.

\section{Example}

As an example of the points raised in the discussion of disequilibrium systems (the choice is based largely on the author's familiarity) consider the chemistry of ground water in the Fox Hills aquifer--a relatively deep $(1,000-2,000 \mathrm{ft})$ aquifer underlying much of the northern Great Plains (see Thorstenson and others, 1979, for details of the chemistry and hydrology). Analytical data for the major redox couples, and calculated pe values, are presented in Table 2 for a recharge area well (Medora) and a downgradient di scharge area we 11 (Hazen) separated by a distance of approximately $150 \mathrm{miles}$. All concentrations are in mmol/1. The entries $p \varepsilon_{E h}$ are $p \in$ values calculated from field Eh measurements (eq. 10), and the values of $p \varepsilon_{S}, p \varepsilon_{\underline{N}}$, and $p \varepsilon_{C}$ refer to analytically calculated potentials from the $\mathrm{SO}_{4}{ }^{2} / \mathrm{HS}^{-}, \mathrm{N}_{2} / \mathrm{NH}_{4}{ }^{+}$, and $\mathrm{HCO}_{3}{ }^{-} / \mathrm{CH}_{4}$ couples respectively. The corresponding values of $\mathrm{pe}^{-}$(aq) are shown in parentheses. Note that in this example, the calculated $p \varepsilon$ values are all within 1 pe unit, misleadingly suggesting near-equilibrium. However, keeping in $\mathrm{mi}$ nd that for the 8-electron reactions between $\mathrm{CH}_{4}: \mathrm{HCO}_{3}^{-}$and $\mathrm{HS}^{-}: \mathrm{SO}_{4}^{2-}$ a single $p \varepsilon$ unit represents a difference of eight orders of magnitude in the activity ratios, Fox Hills water will be considered to be at di sequilibrium wi th respect to redox reactions (a stated that has been maintained for $\simeq 10^{5}$ years based on calculated Darcy's Law flow velocities in the aquifer). 
Table 2. Chemistry of water from the Fox Hills aquifer.

\begin{tabular}{|c|c|c|}
\hline $\begin{array}{l}\text { Constituent } \\
\text { of } \\
\text { Property } \\
\end{array}$ & Medor a We11 & Hazen We11 \\
\hline $\mathrm{pH}$ & 8.83 & 8.60 \\
\hline $\mathrm{SO}_{4}^{2-}$ & 2.29 & 0.031 \\
\hline $\mathrm{HS}^{-}$ & 0.003 & 0.001 \\
\hline $\mathrm{N}_{2}(\mathrm{aq})$ & 0.93 & 0.78 \\
\hline $\mathrm{NH}_{4}^{+}$ & 0.077 & 0.018 \\
\hline $\mathrm{HCO}_{3}^{-}$ & 11.6 & 19.1 \\
\hline $\mathrm{CH}_{4}$ (aq) & 0.0025 & 2.75 \\
\hline$p \varepsilon_{S}\left(p e^{-}(a q)\right)$ & $-5.4(+43.2)$ & $-5.4(+43.2)$ \\
\hline$p \varepsilon_{\mathrm{N}}\left(p \mathrm{e}^{-}(\mathrm{aq})\right)$ & $-5.7(+42.9)$ & $-5.1(+43.5)$ \\
\hline$p \varepsilon_{C}\left(p e^{-}(a q)\right)$ & $-6.0(+42.6)$ & $-6.1(+42.5)$ \\
\hline$p \varepsilon_{\mathrm{Eh}}\left(p \mathrm{e}^{-}(\mathrm{aq})\right)$ & $-1.1(+47.5)$ & $-1.5(+47.1)$ \\
\hline
\end{tabular}

Concentrations of dissolved species are in mol/1iter -1 . Data from Thorstenson and others, 1979. 
Now consider the fate of a redox-active contaminant introduced into the aquifer in trace quantities. If the contaninant species undergoes a valence change (at in situ $\mathrm{pH}$ values) at a calculated pe value between -5 and -6 ( $t$ he observed range for aquifer redox couples), its fate cannot be predicted on a thermodynamic basis. A unique redox potential cannot be defined for these waters, and therefore a knowledge of the final redox state of the contaminant must rest on a knowledge of the specific chemical interactions (which may be microbially catalyzed) of the contaminant withthe major redox-active species in Fox Hills water.

If the contami nant can undergo only a single valence change at $p \varepsilon \simeq-3$ (again at the in-situ $\mathrm{pH} \simeq 8.5$ ) the problem appears simpler at first glance. Al1 of the calculated pe values for the major redox xouples in the two wells lie between -5 and -6 , and even though a unique redox potential cannot be defined it would seem reasonable to "predict" that the contaninant (whose valence changes at $p \varepsilon \simeq-3$ ) would end up in its reduced state.

This apparent simplicity disintegrates when the $\mathrm{Pt}$ electrode measurements (for details and discussion see Thorstenson and others, 1979) are considered. Expressed as $p \varepsilon$, the electrode is responding to an unknown reaction with a potential at $p \varepsilon \simeq-1$ (keep in mind that this e.m.f. results from surface reactions of solutes with the electrode -- the equilibrium $\mathrm{pe}^{-}$(aq) corresponding to the observed Eh's is $\sim 47.6$ ). The fact that the electrode measurements do not correspond to the calculated potentials for the major redox couples is not in itself surprising, since none of these couples are electroactive on Pt. 1 The problem arises in that the contaminant may conceivably respond to the same unknown reactions that the electrode is "seeing," in which case the contaminant would end up in $i$ ts oxidized, rather than reduced, form.

The possiblity also exists that the contaminant will repond to neither the "electrode reaction" nor the major redox couples, but to some other unknown process -- perhaps involving sorption and reaction on mi neral surfaces.

In considering the problem of contaminants introduced into natural waters, the following generalization can be made. The information on speciation of the contaminant contained in potential-pH diagrams is useful, but, for predicting the contami nant's behavi or in natural waters, these diagrams are, to use Clark's words, a "tentative expedient." Whether the relations embodied in the diagrams are realized in nature depends totally on the specific reactions between the contaminant and the particular redox-active couples in the environment to which it is introduced. The only potentially definitive approach to the problem of predicting the contaminant's fate would appear to be in situ field testing.

$1 /$

See Whitfield (1974) for additional discussion of the thermodynamic limitations on platinum electrode measurements. 
Contrast the above with the information needed to predict the acid-base reactions in Fox Hills water. With the measurement of $\mathrm{pH}$ (which is essentially constant in this aquifer throughout the entire southwestern quarter of North Dakota), the only information needed is whether, on the time scale in question, reactions of the contaminant with $\mathrm{H}^{+} / \mathrm{OH}^{-}$are rapid. If these reactions are rapid, prediction of the aqueous speciation of a contaminant is limited only by the reliability of the thermodynamic data and the aqueous model used for the calculation. Even if the reactions are slow, prediction of the equilibrium speciation of the contaminant in the aqueous phase--and, thus, the direction in which reactions should proceed-are subject only to the same limitations.

Based on the information presented in this paper, an equivalent statement cannot be made for redox potential.

\section{Practical Considerations}

Given the general inability to define a thermodynamic redox potential in natural aqueous systems, the obvious question arises as to the nature of data that should be collected to provide useful information with repect to naturally ocurring redox reactions. A very useful paper pertaining to this problem has been published recently by Berner (1981).

The emphasis of Berner's paper is on the classification of the environments of deposition and early diagenesis of recent sediments. Berner refers to sedimentary environments as "oxic", "post-oxic", "sulfidic", and "methanic" (see fig. 3). This classification is based on an assumed practical limit of analytical detectability of 1 mol/liter for the dissolved substances in question, and that this concentration also approximates the general limits of utilization by microorganisms.

Some of the concepts embodied in Berner's paper are also particularly well suited to the study of redox potentials in ground waters, although the classification has genetic implications that may represent some oversimplification when applied to groundwater systems. If used in groundwater studies the terminology might perhaps be modified to: oxygenated ("oxic"), iron-rich ("post-oxic); sulfide-rich ("Sulfidic); and methane-rich ("Methanic"). It must be emphasized that this is primarily a semantic point, and in fact Berner's terminology will. be used in the following discussion.

The basic premise underlying Berner's classification is that the transition from initially oxygented water to "reduced" methane-rich pore water is driven by the decomposition of organic matter. This is probably also true for the great majority of groundwater systems (see Foster, 1950; Edmunds, 1982; Champ, and others, 1979; Thorstenson, and others, 1979; Freeze and Cherry, 1979; Baedecker and Back, 1979, Pearson and Rettman, 1976; Deike and Pearson, 1978; and references cited by these authors). Some brief comments on specific environments follow. 


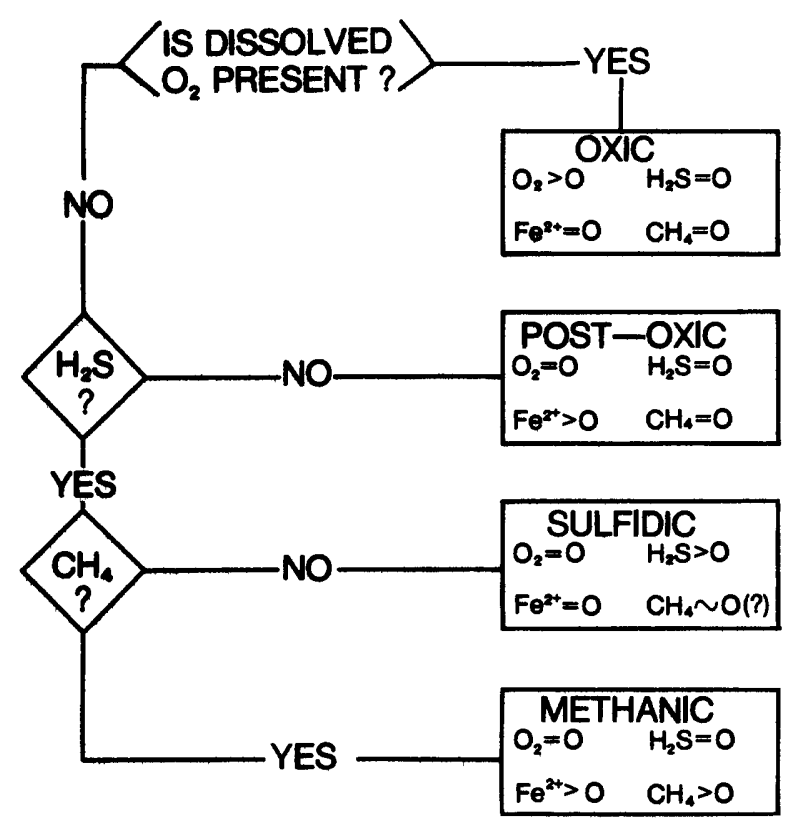

Figure 3. The chemical basis for Berner's sedimentary environment classification; ad apted from Berner (1981). 
Oxic groundwaters. Except. in shallow recharge areas, groundwaters have been generally assumed to be oxygen-free. An important paper by Wil nograd and Robertson (1982) demonstrates this premise to be false; when analyses are performed (which has been seldom), dissolved oxygen is found in a variety of groundwater systems, including deep regional aquifers. Note that the presence or absence of dissolved $\mathrm{O}_{2}$ cannot be determined by $\mathrm{Pt}$ electrode measurements (see Sato, 1960).

Sulfidic groundwaters. Aquifers that fit this category are abundant - in general, as in sediment pore waters, the sulfide appears to be generated by sulfate reduction. Some examples are reported by Edmunds, 1983; Busby and others, 1985; Champ and others, 1978; Thorstenson and others, 1979; Rye and others, 1981.

Post - Oxic or Methanic groundwaters: In Berner's classification, both of these reducing environments are characterized by high levels of dissolved iron, permitted by the absence of dissolved sulfides, but for different causes. In post - oxic waters, organic decomposition has been slight, and sulfate-reduction has not started, or is in its earliest stages. In methanic waters, organic decomposition has proceeded to the point of methane-producing fermentation reactions, after complete sulfate reduction has occurred and sulfide has been precipitated as iron sulfides.

Sufficient data (in this case dissolved methane analyses) a re not avallable to determine whether general categories of "post - oxic" and "methanic" groundwaters can be distinguished. Abundant dissolved methane is present in many aqui fer systems (D.W. Fisher, personal comm.; Busby and others, 1985; Thorstenson and others, 1979). On the other hand, there are many high-iron groundwaters in which the abundance of methane is unknown (see Foster, 1950; Hem, 1970, p. 114126; Wi nograd and Farlekas, 1974; Barnes and Back, 1964; Nordstrom and others, 1979a; Crerar and others, 1981). The question here is thus whether or not a groundwater analogy to Berner's "post-oxi c" sedimentary envi ronment actually exists.

\section{Interpretation and Modeling of Redox Processes}

Some care needs to be exercised in applying the points raised in the preceding discussion to the interpretation of natural redox processes. There is no question that the theoretical relations embodied in the abundant literature on potential (as Eh or $\mathrm{p} \varepsilon$ ) - $\mathrm{pH}$ di agrams provides invaluable insight into sequences of mi neral paragenesis and sequences of redox reactions observed in natural waters. Large numbers of examples are di scussed in virtually all of the references cited in this paper, and are not pursued further here.

The opportunity for misinterpretation arises if the above reaction sequences are discussed in terms of "the redox potential" of the aqueous phase during the reactions. One example has already been presented in terms of the Fox Hills aquifer; consider another in terms of the reactions that form the basis for Berner's sediment classification. 
There is no question that if initially oxygenated water is introduced to an organic-rich envi ronment (or vice versa), a series of redox reactions will occur that results ultimately in a reducing, methane-rich envi ronment. This reaction sequence has been observed many times, both in sediment pore waters and in the eutrophication of surface waters. However, these reactions represent a disequilIbrium process (organic decomposition) and at no point in the reaction sequence can a unique redox potential be defined for the reacting system.

Further removed from reality is the attempt to use measured Eh values to represent "the redox potential" as these reactions progress. Although a general decrease in measured potentials will be observed as the reactions progress (see Stumm, 1967, and Whitfield, 1969, for a discussion of $E h$ as an "operational parameter"), quantitative, and, in general, semi-quantitative interpretation of the measured e.m.f.'s as redox potentials is meaningless. Few of the reactions involved are electroactive; most are microbially catalyzed; and (as pointed out earlier) the Eh measurements cannot differentiate between oxic and post-oxic initial reaction conditions because of the irreversible oxygen potential registered by the platinum electrode.

Chemical Modeling

At this point, some discussion is in order regarding the use of redox potential in the various computer codes now available for calculating aque ous speciation (Nordstrom and others, 1979b, provide an excellent summary) and reaction paths (Helgeson and others, 1970; Wolery, 1979; Parkhurst and others, 1980). No attempt is made here to compare details of individual computer codes; each has its advantages and disadvantages.

The speciation programs compute chemical speciation in the aqueous phase based on available analytical data. To whatever extent possible, the speciation calculations should be made independent of the possible redox interactions between species. For example, if analytical data show a water to contain dissolved sulfate, sulfides, nitrogen, and ammonia, the speciation of total $\mathrm{SO}_{4}{ }^{2-}, \mathrm{s}^{2-}$, and $\mathrm{NH}_{4}^{+}$should be made without "coupling" these species via the appropriate redox reactions. If the calculations are made with a single value for redox potential and "coupled" reactions, the resulting calculations will be error unless the redox couples involved were initially at equilibrium in the original water sample.

Another major use of the speciation calculations lies in the estimation of saturation indexes of the water with respect to various mineral phases. Reliable estimates (wi thin uncertainties in analytical methods and thermodynamic data) of saturation indexes can be made when there is no change in valence between aqueous species and the mineral in question. For example, the saturation state of a water with respect to siderite may be calculated if analyses of dissolved $\mathrm{Fe}^{2+}$ are available because the reaction

$$
\mathrm{Fe}^{2+}(\mathrm{aq})+\mathrm{CO}_{3}{ }^{2-}(\mathrm{aq})=\mathrm{FeCO}_{3}
$$

does not require a knowledge of redox potential for equilibrium calculations. 

as in

On the other hand, if valence changes are required for mi neral formation,

$$
\mathrm{Fe}^{2+}(\mathrm{aq})+2 \mathrm{H}_{2} \mathrm{O}(1)=\mathrm{FeOOH}_{(\mathrm{s})}+2 \mathrm{H}^{+}(\mathrm{aq})+\mathrm{e}^{-}(\mathrm{aq}) \text {, }
$$

a numerical value of redox potential or electron activity is required for calculation of a saturation index. If an Eh measurement is used as the basis for making the saturation calculations, the accuracy of the estimated saturation index depends entirely on the degree to which the electron transfer reactions between the aqueous species in question and the surface of the platinum electrode mimic the electron transfer reactions to the electron donor/receptor in the natural system. Experience suggests that in general this agreement is poor.

Similar problems must be addressed if reaction-path modeling of redox processes is attempted. For example, Thorstenson (1970) calculated reaction paths for decomposition of organic matter in natural waters using the simplistic assumption that complete equilibrium is maintained among all aqueous species. The calculations are consistent with several features of natural eutrophication processes, but "predict" changes in concentrations of dissolved $\mathrm{N}_{2}$ that are not observed in natural environments. A more representative description would have been obtained by excluding $\mathrm{N}_{2}$ from the calculations.

This points up one of the major dangers of reaction-path modeling, namely the temptation to use the models as predictive tools. The dangers involved are present in attempts to predictively model any system, but are particularly appropriate to redox reactions because of the abundant kinetic problems that exist with redox reactions. As has already been illustrated by the example of computing the valence state of a contaminant introduced to Fox Hills groundwater, predictive modeling cannot be done without specific knowledge of the reaction kinetics of the particular redox couples under consideration.

Despite the potential for mi sinterpretation of reaction path models, there is one important problem in redox chemistry whose solution may be avai1able only through the use of reaction path models. The redox potential, like $\mathrm{pH}$, is an intensive variable; a knowledge of the redox potential of an equi1ibrium system provides no information as to the capacity of the system to buffer, or poise, the redox potential of the system as reactants are added to $i t$. In many instances, a knowledge of the poising capacityl/ of a natural system with respect to addition of oxidants or reductants added to it may be of more practical consequence than a detailed knowledge of the specific state of individual redox couples in the system. Particularly for systems involving heterogeneous reactions, careful use of reaction path models may provide the only practical approach to this problem.

\footnotetext{
1/ Attempts to define the poising capacity of particular aqueous systems have been made by Thorstenson (1970) and Brewer and Murray (1973).
} 
In conjunction with an attempt to categorize concepts of reaction path modeling as applied to redox processes, considerable effort was devoted to trying to define an "effective" redox potential in an aqueous system based on relative amounts of various redox couples in the system relative to the amounts of reactants (natural or anthropogenic) added to the system. All of the categorization schemes eventually broke down - no unequivocal way of defining an "effective" redox potential emerged.

Eventually, it was recognized that, given a set of initial conditions, the only thing that can be unequivocally calculated is the ultimate equilibrium state of the system. Identification of the particular pathway towards equilibrium, (that is predictive reaction modeling) is thus in fact a formal problem in disequilibrium thermodynamics - a problem that has received relatively 1ittle attention in aqueous geochemistry. A few papers of interest include the following: Hem and others (1983) have applied disequilibrium thermodynamics to the behavior of Mn in natural waters; Harris (1982) evaluates problems of applying thermodynamics to microbial systems, specifically to nitrogen transformation in solls; Plumer and others (1983) attempt to define thermodynamic constraints within which these reactions must occur.

The thermodynamic constraints that can be placed on reacting systems are very general - the system free energy must proceed towards a minimum, and individual (or coupled) reactions must proceed with a decrease in free energy at any point in the reaction. These thermodynamic constraints are broad; the reaction paths are non unique. In general, many reaction paths towards equilibrium exist that can satisfy the necessary thermodynamic constraints.

Except in the rare cases where natural systems can be approximated as equilibrium systems, attempts at modeling redox processes are thus a fundamental problem in disequilibrium thermodynamics. It thus seems clear that if a predictive capability is desired for the redox behavior of chemicals introduced into natural aqueous environments, complete chemical analyses of all redox couples present in the environment are a necessity. Kinetic data on reactions between the naturally occurring species and the contaminant will also be necessary, and if rigor in the predictive attempt is needed, then information on reactions at mineral surfaces would also be imperative. It is difficult to avoid the conclusion that in situ field studies are a necessity for developing a predictive model of any natural system. 


\section{REMARKS}

There is little in this paper that can be said to be fundamentally new. The thermodynamic aspects of this work were complete by 1930; the hydrated electron free energy is not grossly different from values estimated by 1965. Baas Becking and others (1960), in the most extensive review of fleld Eh and $\mathrm{pH}$ measurements to date, concluded that many geologically distinct environments could not be differentiated by their Eh-pH characteristics; the same conclusion led Berner (1981) to propose his new classification of sedimentary environments. The inability to define redox potentials in disequilibrium systems was recognized by Morris and Stumm (1967, p. 284), Stumm and Morgan (1970, p. 363) and Stumm and Morgan (1981, p. 462), and has recelved extensive documentation in ground waters by Lind berg and Runnells, 1984.

The aim of the present paper is to attempt to shift the emphasis in comparing acid-base and redox processes from similarity via the $p \varepsilon-p H$ analogy to an emphasis on the dissimilarity. The classic paper of Sillen (1967) states that the electron should be treated like any other reagent and stresses the pe-pH analogy; Table 1 suggests that in fact $e_{(a q)}^{-}$differs profound ly from the hydrated proton $\mathrm{H}_{(}^{+}(a q) \cdot$ The entire literature on $\mathrm{Eh}-\mathrm{pH}$ diagrams suggests (in this author's opinion) that the long-recognized problems in interpreting Eh measurements are believed to stem primarily from problems in measurement technique, rather than recognizing the lack of a unique potential to measure.

Hopefully, de-emphasizing the concept of "the redox potential" will lead to a better understanding and ability to deal with "redox processes" in natural environments.

\section{CONCLUSIONS}

1. The absence of hydrated electrons except in irradiated waters precludes the possibility of directly measuring an electron activity in aqueous solution.

2. In disequilibrium systems, electron activity can be neither defined nor measured. Becaitse essentially all natural waters are at disequilibrium with respect to redox reactions, this leads to the conclusion that for all practical purposes unique redox potentials in natural waters do not exist. This would appear to account for much of the troubled history of Eh measurements in natural waters.

3. The mathematical analogy between the equations describing $\mathrm{p} \varepsilon$ and $\mathrm{pH}$ is misleading. The hydrated proton does in fact exist in all waters; the analogous hydrated electron ordinarily is not present in aqueous solutions, and therefore does not participate in the redox reactions of water systems. 
4. The most important application to be derived from this paper pertains to the wide variety of environmental studies and proposals that involve an attempt to evaluate "the redox potential" of an envi ronment. Based on the information presented here, "the redox potential" does not, in general, exist and attempts to measure it by electrode, or with analytically calculated potentials, must fail. If the redox chemistry of a natural system is of real concern the maximum benefit will be obtained from directing efforts towards analysis of as many redox couples in the system as is practical. In short, it will be the reactions (or lack of) between reactants and specific redox-active species in the environment that determine the ultimate redox state of the system, not the response of the reactants to "the redox potential of the envi ronment".

5. Because neither electrode measurement nor analytically calculated potentials can define a unique redox potential for the aqueous phase, "prediction" of reactions must be based on kinetic data and field observation. It would be extremely difficult, for example, based on laboratory studies alone, to evaluate the in-situ redox reactions between solutes and solid phases in the system. Considerations such as this imply that if prediction is sought for the redox behavior of contaminants in a natural system, for example toxic wastes in ground water, it would appear that field studies (in-situ) are a necessity.

\section{ACKNOWLEDGMENTS}

This paper would not have been written without the study of the the rmodynamics of hydrated electrons carried out by John D. Hostettler, Chemi stry Department, San Jose State University; John also provided continuing revi ew and discussion throughout much of the writing of this manuscript.

This paper was vastly improved thanks to reviews by many of the author's colleagues at the U.S. Geological Survey - John Busby, Ed Busenberg, Blair Jones, Niel Plummer, and Ike Winograd; particularly extensive and insightful revi ews were provided by Don Fisher, John Hem, and Kirk Nordstrom. The help of all of these individuals is gratefully acknowledged. Not surprisingly, total accord between all reviewers and the author was never completely achieved. The responsibility for the content of this paper lies with the author.

Finally, the typing and patience of Betty Hudner throughout the seemingly interminable preparation of this paper is greatly appreciated.

\section{REFERENCES}

Baas-Becking, L. G. M., Kaplan, I. R., and Moore, D., 1960, Limits of the natural envi ronment in terms of $\mathrm{pH}$ and oxidation-reduction potentials: Journal of Geology, v. 68, p. 243-284.

Baedecker, M. J., and Back, W., 1979, Modern marine sediments as a natural analog to the chemically stressed environment of a landfill: Journal of Hydrology, v. 43, p. 393-414. 
Baes, C. F. Jr., and Mesmer, R. E., 1976, The hydrolysis of cations: New York, John Wiley and Sons, 489 p.

Barnes, I., and Back, W., 1964, Geochemi stry of i ron-rich ground waters of southern Maryland: Journal of Geology, v. 72, p. 435-447.

Bates, R. G., 1973, Determi nation of pH: New York, John Wiley and Sons, 479 p.

Baxendale, J. H., 1964, Redox potential and hydration energy of the hydrated electron: Radiation Research Supplement, v. 4, p. 139-140.

Berner, R. A., 1963, Electrode studies in hydrogen sulfide in marine sediments: Geochimi ca et Cosmochimi ca Acta, v. 27, p. 563-575.

- 1971, Principles of chemical sedimentology: New York, McGraw-Hil1, 240 p.

- - ---, 1981, A new geochemical classification of sedimentary envi ronments: Journal of Sedimentary Petrology, v. 51, p. 359-365.

Bockris, J. O. M., and Reddy, A. K. N., 1970, Modern electrochemi stry: New York, Plenum Press, 1432 p.

Boulegue, J. 1978, Electrochemi stry of reduced sulfur species in natural waters - I. The $\mathrm{H}_{2} \mathrm{~S}-\mathrm{H}_{2} \mathrm{O}$ system: Geochimica et Cosmochimica Acta, v. 42, p. $1439-1445$.

Boulegue, J. and Michard, G., 1979, Sulfur speciations and redox processes in reducing environments, Ch. 2, in Jenne, E. A., ed., Chemical modeling in aqueous systems: Speciation, sorption, solubility, and kinetics: Washington, D.C., American Chemical Society Symposium Series 93, p. 25-50.

Breck, W. G., 1972, Redox potentials by equilibration: Journal of Marine Research, v. 1, p. 121-139.

Brewer, P. G., and Murray, J. W., 1973, Carbon, nitrogen, and phosphorous in the Black Sea: Deep Sea Research and Oceanographic Abstracts, v. 20, p. 803-818.

Bricker, 0. P., 1965, Some stability relations in the system $\mathrm{Mn}-\mathrm{O}_{2}-\mathrm{H}_{2} \mathrm{O}$ at $25^{\circ} \mathrm{C}$ and one atmosphere total pressure: American Mineralogist, v. 50, p. 1296-1354.

Brónsted, J.N., 1929, Über acidi tät und ionen-potentiale:, Zeitschr. physik. Chemi e, Abt. A, v. 143, p. 301-312.

- - , J. N., 1943, Fysik Kemi, 2. Udg. Kobenhavn. Cited in Jфrgensen, 1945, p. 11 .

Busby, J. F., Plumme r, L. N., Lee, R. W., and Hanshaw, B. B., 1985, Geochemi cal evolution of ground water in the Madison aquifer system in the northern Great Plains in parts of Montana, Wyoming, and South Dakota: U.S. Geological Survey Professional Paper xxxx, in press.

Castellan, G. W., 1970, Physical chemi stry, 2d edition: Reading, MA, Addi sonWesley, 769 p. 
Champ, D. R., Gulens, J., and Jackson, R. E., 1979, Oxi dation-reduction sequences in ground water systems: Canadian Journal of Earth Science, v. 16, p. 12-23.

Clark, W. M., 1922, The determi nation of hydrogen ions, 2d edition: Baltimore, Williams and Wilkins Co., 480 p.

,1928, The determi nation of hydrogen ions, 3d ed.: Baltimore, Williams and Wilkins Co., 717 p.

Crerar, D. A., Means, J. J., Yuretich, R. F., Borcsik, M. P., Amster, J. L. , Hastings, D. W., Knox, G. W., Lyon, K. E., and Quiet t, R. F., 1981, Hydrochemi stry of the New Jersey Coastal Plain 2. Transport and deposition of alumi num, dissolved organic mater, and selected trace elements in stream, ground- and estuary water: Chemi cal Geology, v. 33, p. 23-44.

Deike, R. G., and Pearson, F. J., Jr., 1978, Mineral alteration by ground water in the Edwards Aquifer, Texas: 10th International Congress on Sedimentology, Israel, Abstracts, v. 1, p. 163.

Deutsch, W. J., Jenne, E. A., and Krupka, K. M., 1982, Solubility equlibria in basalt aquifers: the Columbia Plateau, eastern Washington, U.S.A.: Chemical Geology, v. 36 , p. 15-34.

Doyle, R. W., 1968, The origin of the ferrous ion-ferric oxide Nernst potential in environments containing dissolved ferrous iron: American Journal of Science, v. 266 p. 840-859.

Edmunds, W. M., Bath, A. H., and Miles, D. L., 1982, Hydrochemilcal evolution of the East Midlands Triassic sandstone aquifer, England: Geochimica et Cosmochimica Acta, v. 46, p. 2069-2082.

Foster, M. D., 1950, The origin of high sodium bicarbonate waters in the Atlantic and Gulf Coastal Plain: Geochimica et Cosmochimica Acta, v. 1, p. 33-48.

Freeze, R. A., and Cherry J. A., 1979, Groundwater: Englewood C11 ffs, New Jersey, Prentice-Hall, Inc., 604 p.

Garrels, R. M., and Christ, C. L., 1965, Solutions, mi nerals, and equilibria: New York, Harper and Row, 450 p.

Giguere P. A., 1979, The great fallacy of the $\mathrm{H}^{+}$i on: Journal of Chemi cal Education, v. 59, p. 571-579.

Guggenheim, E. A., 1929, The conception of electrical potential difference between two phases and the individual activities of ions: Journal of Physical Chemi stry, v. 33, p. 842-849.

--, 1930, On the conception of electrical potential difference between two phases II: Journal of Physical Chemi stry, v. 34, p. 1540-1543.

1949, Thermodynamics: New York, Interscience Publishers Inc., 394 p. 
Harris, R. F., 1982, Energetics of nitrogen transformations, in Nitrogen in agricultural soils: Madison, Wi sconsi n, Agronomy Monograph no. 22, ASA - CSSA SSSA, p. 833-889.

Harned, H. S., and Owen, B.B., 1958, The physical chemistry of electrolytic solutions: American Chemical Society Monograph No. 137, New York, Reinhold Publishing Corp., 803 p.

Hart, E. J., and Anbar, M., 1970, The hydrated electron: Willey Interscience, New York.

Helgeson, H. C., Brown, T. H., Nigrini, A., and Jones, T. A., 1970, Calculation of mass transfer in geochemical processes involving aqueous solutions: Geochimi ca et Cosmochimi ca Acta, v. 34, p. 569-592.

Hem, J. D., 1970, Study and interpretation of the chemical characteristics of natural water: U.S. Geological Survey Water-Supply Paper 1473, 363 p.

Hem, J. D., Roberson, C. E., and Fournier, R. B., 1983, Stability of BMnOOH, and manganese oxide deposition from spring water: Water Resources Research, v. 18, p.

Hostettler, J. D., 1983, Electrode electrons, aqueous electrons, and redox potentials in natural waters:- American Journal of Science, p. 734-759.

International Union of Pure and Applied Chemi stry, 1970, Manual of symbols and terminology for physicochemical quantities and units: London, Butte rworths, 44 p.

Jorgensen, H., 1945, Redox-maalinge $\mathrm{r}$ : Copenhagen, Gjellerups, 43 p. (Translation by U.S Joint Publications Research Service, Arlington, VA).

Jortner, J., and Noyes, R. M., 1966, Some thermodynamic properties of the hydrated electron: Journal of Physical Chemistry, v. 70, p. 770-774.

Kolthoff, I. M., 1930, Rec. Trav. Chim., v. 49, p. 401, cited in Bates, 1973, p. 11.

Krumbei n, W. C., and Garrels, R. M., 1952, Origin and classification of chemical sediments in terms of $\mathrm{pH}$ and oxidation-reduction potentials: Journal of Geology, v. 60, p. 1-33.

Langmuir D., and Whittemore, D. 0., 1971, Variations in the stability of precipitated ferric oxyhydroxides in Nonequilibrium Systems in Natural hater Chemi stry, Washingt on, D. C., Ame rican Chemi cal Society Advances in Chemi stry Series no. 106, p. 209-234.

Lehfeldt, R. A., 1899, On the theory of the electrolytic solution-pressure: Phi1. Mag. v, 48, p. 430., cited in Clark, 1922, p. 246.

Lewis, G. N., 1913, The free energy of chemical substances: Journal of the American Chemical Society, v. 35, p. 1-30. 
Lewis, G. N., and Randa11, M., 1923, Thermodynamics and the free energy of chemical substances: New York, McGraw-Hil1, 653 p.

Li ndberg, R. D., and Runnells, D. D., 1984, Ground water redox reactions: An analysis equilibrium state applied to $\mathrm{Eh}$ measurements and geochemical modeling: Science, v. 225, p. 925-927.

Mi chaeli s, L., 1930, Oxidation-reduction potentials: Philadelphia, J.B. Lippincott, 317 p.

Mø1 ler, M. (1936) KEMISK, v. 17, p. 141. Ci ted in Jorgensen, 1945, p. 11.

Morris, J. C. and Stumm, W., 1967, Redox equilibria and measurements of potentials in the aquatic envi ronment, in Gould, R.F. ed., Equilibrium concepts in natural water systems: Washington, D.C., American Chemi cal Society Advances in Chemi stry Series No. 67, p. 270-285.

Nernst, W., 1897, Die elektrolytische Zersetzung wassriger Losungen: Ber., v. 30 , p. 1547-1563.

Nordstrom, D. K., Jenne, E. A., and Ball, J. W., 1979a, Redox equilibria of iron in acid mine waters, in Jenne, E.A., ed., Chemical modeling in aqueous systems. Speciation, sorption, solubility and kinetics: Washington, D.C., Ame rican Chemical Society Symposium Series 93, p. 51-79.

Nordstrom, D. K., Plummer, L. N., Wigley, T. M. L., Wolery, T. J., Ba1l, J. W., Jenne, E. A., Bassett, R. L., Crerar, D. A., Florence, T. M., Britz, B., Hof fman, M., Holdren, G. R., Jr., Lafon, G. M., Mattigod, S. V., McDuff, R. E., Morel, F., Reddy, M. M., Sposito, G., and Thrailkill, J. , 1979b, A comparison of computerized chemical models for equilibrium calculations in aqueous systems: in Chemical modeling in aqueous systems, Speciation, sorption, solubility, and kinetics, Jenne, E.A., ed., Ame rican Chemi cal Society, Symposi um series 93, p. 857-892.

Parkhurst, D. L., Thorstenson, D. C., and Plummer, L. N., 1980, PHREEQE - A computer program for geochemical calculations: U.S. Geological Survey Water-Resources Investigations $80-96,210 \mathrm{p}$.

Pearson, F. J., Jr., and Rettman, P. L., 1976, Geochemi cal and Isotopic analyses of waters associated with the Edwards Limestron Aquifer, Central Texas: U.S. Geological Survey Report of Investigations, 35 p.

Peters, R., 1898, Uber oxydations-und Reductionsketten und den Einfluss komplexer Ionen auf ihre elektromotorische Kraft: Zeitschr. physik. Chemie, v. 26, p. 193.

Plummer, L. N., Parkhurst, D. L., and Thorstenson, D. C., 1983, Development of reaction models for ground-water systems: Geochimica et Cosmochimica Acta, v. 47, p. 665-686.

Psurbaix, M., 1966, Atlas of electrochemi cal equilibria in aqueous solutions: New York, Pergamon Press, 670 p. 
Rye, R. 0., Back, W., Hanshaw, B. B., Rightmi re, C. T., and Pearson, F. J., Jr., 1981, The origin and isotopic composition of dissolved sulfide in groundwater from carbonate aquifers in Florida and Texas: Geochimica et Cosmochimica Acta, v. 45, p. 1941-1950.

Sato, M., 1960, Oxidation of sulfide ore bodies, I. Oxidation mechanisms of sulfide minerals at $25^{\circ} \mathrm{C}$. : Economic Geology, v. 55, p. 1202-1231.

Sillen, L. G., 1952, Redox diagams: Journal of Chemical Education, v. 29, p. 600-608.

- - - 1967, Master variables and activity scales, Ch. 3, in Gould, R.F., ed., Equilibrium Concepts in natural water systems, Washington, D.C., Ame rican Chemi cal Society Advances in Chemi stry Series, No. 67, p. 45-56.

Sфrensen, S. P. L., 1909, Enzymstudien. II. Uber die Messung und di e Bedeut ung der Wasserstoffioneukonzentration bel enzymatischen Prozessen: Biochem. Z., v. 21, p. 131; continuation, v. 21, p. 201 (1909); Cempt. Kend. Trav. Lab. Carlsberg, v. 8, p. 1 (1909). Cited in Bates, 1973, p. 17 .

Sфrensen, S. P. L., and Linderstr bm-Lang, K., 1924, Compt. Red. Trav. Lab. Carlsberg, v. 15, No. 6. Cited in Bates, 19.73, p. 21.

Stumm, W., 1967, Redox potential as an environmental parameter: Conceptual significance and operational limitation: Advances in Water Pollution Research, v. 1 , p. 283-308.

Stumm, W., and Morgan, J. J., 1970, Aquatic chemi stry: New York, John Wiley and Sons, 583 p.

- - W., and Morgan, J. J., 1981, Aquatic chemi stry, 2d edition: New York, John Wiley and Sons, 780 p.

Thorstenson, D. C., 1970, Equilibrium distribution of small organic molecules in natural waters: Geochimica et Cosmochimica Acta, v. 34, p. 745-770.

Thorstenson, D. C., Fisher, D. W., and Croft, M. G., 1979, The geochemi stry of the Fox Hills-Basal Hell Creek Aquifer in Southwestern North Dakota and Northwestern South Dakota: Water Resources Research, v. 15, p. 1479-1498.

Truesde11, A. H., 1968, The advantage of using $p \varepsilon$ parameter rather than Eh in redox equilibrium calculations: Journal of Geological Education, v. 16, p.17-20.

Whitfield, M., 1969, Eh as an operational parameter in estuarine studies: Limnology and Oceanography, v. 14, p. 547-558.

M., 1974, The rmodynamic limitations on the use of the platinum electrode in Eh mesurements: Limnology and Oceanography, v. 19, p. 857-865. 
Winograd, I. J., and Farlekas, G. M., 1974, Problems in ${ }^{14} \mathrm{C}$ dating of water from aquifers of deltaic origin. An example from the New Jersey coastal plain: in Isotope techniques in groundwater hydrology, v. II., Vienna, International Atomic Energy Agency, p. 69-93.

Winograd, I. J., and Robertson, F. N., 1982, Deep oxygenated ground water: Anomaly or common occurrence?: Science, v. 216, p. 1227-1230.

Wolery, T. J., 1979, Calculations of chemical equilibrium between aqueous solutions and minerals: The EQ 36 software package: NTIS UCRL-52658, 41 p.

ZoBe11, C. E., 1946, Studies on redox potential of marine sediments: Bulletin of the American Association of Petroleum Geologist s, v. 30, p. 477-513. 


\section{FIGURE CAPTIONS}

Figure 1. Schematic representation of an Eh measurement. S.H.E. refers to the Standard Hydrogen Electrode. If the liquid junction potential across the salt bridge is zero, the electrical potentials of the sample and the S.H.E. are the same, regardless of the measured voltage across the electrodes; that is, regardless of the Eh of the sample.

Figure 2. The water stability field presented as a function of pH vs. $\mathrm{pe}^{-}(\mathrm{aq})$, $\mathrm{p} \varepsilon$, and $\mathrm{Eh}$.

FIgure 3. The chemical basis for Berner's sedimentary envi ronment classification; adapted from Berner (1981).

U.S. GOVERNMENT PRINTING OF FICE: 1985-461-431/10141 